\title{
Review \\ The use of water resources for inland fisheries in South Africa
}

\author{
JR McCafferty ${ }^{1}$, BR Ellender ${ }^{1}$, OLF Weyl2* and PJ Britz ${ }^{1}$ \\ ${ }^{1}$ Department of Ichthyology and Fisheries Science, Rhodes University, Grahamstown 6139, South Africa \\ ${ }^{2}$ South African Institute for Aquatic Biodiversity (SAIAB), Private Bag 1015, Grahamstown 6139, South Africa
}

\begin{abstract}
The contribution of inland fisheries to food security, livelihood provision, poverty alleviation, and economic development in developing African countries is well documented, but there is surprisingly little literature on the history, current status and potential of South Africa's inland fishery resources. This presents a constraint to the management and sustainable development of inland fisheries. A literature review of peer-reviewed and grey literature was thus undertaken which is presented as a synthesis of knowledge on inland fisheries in South Africa. We track the chronology of literary themes on inland fisheries from the colonial era to the present, provide an overview of the recreational, subsistence and commercial sub-sectors, the production potential of inland waters, interventions to promote fishery development, and attempts to value inland fisheries. The review summarises the current state of knowledge on fisheries resources, outlines potential sources of data, highlights relevant and important information, and identifies knowledge gaps. The literature survey reveals an urgent need for research covering the biological, social, economic and governance aspects, if inland fisheries are to be developed in a rational and sustainable manner which promotes South Africa's national policy goals.
\end{abstract}

Keywords: yield, alien, angling, CPUE, impact, value of inland fisheries, information, sectors, potential

\section{Introduction}

The latest comprehensive assessment of global inland fisheries in 2003 estimated the total harvest at 8.7 million tons, which accounted for $6 \%$ of global fish production (FAO, 2003). While the inland fisheries contribution on a global scale is relatively small, Neiland et al. (2005) caution that simple comparisons of gross production can be misleading because inland fisheries in many developing countries and regions generate a wide variety of benefits for millions of people. Such benefits include food security, the provision of livelihoods, and contributions to wealth and wellbeing of communities engaged in a variety of fisheries-linked activities that collectively contribute significantly to both rural and national economies (Kapetsky and Petr, 1984; Van der Knaap, 1994; Geheb and Binns, 1997; Sarch and Allison, 2000; Allison et al., 2002; Allison, 2005).

In Africa, the role of inland fisheries as vehicles for rural development, poverty reduction, food security, livelihood provision and regional economic development are being increasingly recognised (Marshall and Maes, 1994; FAO, 2003), and fisheries have been identified as a priority investment area by the African Union (NEPAD, 2005).

In South Africa, there is also an increasing interest in developing the economic and social opportunities offered by inland capture fisheries. Such development will, however, need to take into consideration the dynamic nature of the current users of the fish resources, which are mainly subsistence and recreational anglers (Weyl et al., 2007; Ellender et al., 2009 ; 2010b). Commercial fisheries remain poorly developed despite several attempts to develop these fisheries, dating back to the 1970s (Jackson, 1980; Koch and Schoonbee, 1980;

\footnotetext{
* To whom all correspondence should be addressed.

鬲 +27 46603 5800; fax: +27 466222403 ;

e-mail: o.weyl@saiab.ac.za

Received 16 May 2011; accepted in revised form 2 April 2012.
}

Allanson and Jackson, 1983; Cochrane, 1987; Andrew, 2001). Possible reasons for the lack of inland fisheries development are cited as: a paucity of natural water bodies where a culture of fishing may have developed; a lack of access to fishing gear; market resistance to freshwater fish; availability of relatively cheap marine fish products; and a lack of knowledge of the potential of the resource (Andrew, 2001; Weyl et al., 2007). Significantly, South Africa has never had an inland fisheries policy, and the potential socio-economic value of fisheries has not been recognised in South Africa's water resource management policies (Weyl et al., 2007). As a result, the responsibility for access to dams and their fishery resources is currently fragmented between government departments and is not directed by a coherent policy. This lack of a national policy was, and remains, a major bottleneck in the development of inland fisheries (Weyl et al., 2007).

Fishery management was historically the mandate of the provincial nature conservation authorities, who managed the resource primarily for recreational purposes in terms of South Africa's environmental legislation (Hey, 1977). As the conservation departments did not have a development mandate, there was not much capacity to support the development of livelihoods based on fisheries, although a number of projects were promoted in some provinces. This, coupled with a low direct value of freshwater fish (ZAR 6/kg, Ellender et al., 2010b), and in some cases apartheid exclusion of people from accessing resources, has resulted in South African inland fisheries being utilised primarily by recreational anglers (Weyl et al., 2007).

More recently, however, there is evidence of increasing utilisation of inland fisheries by subsistence anglers (Van der Waal et al., 2000; Ellender et al., 2009). While subsistence anglers from local communities are generally regarded as having a legitimate claim to fish, in the absence of a supporting governance framework their activities are in many cases illegal. This has led to conflicts between water users on a number of impoundments (Weyl et al., 2007; Weyl et al., 2010a). 
South Africa's national policy objectives in respect of natural resource use include: food security; economic empowerment; tourism development; optimal economic benefit from water; and poverty eradication (ECA, 1989; NEMA, 1998; NWA, 1998). Given these objectives, the formulation of an inland fishery policy needs to take into account the potential of the different fisheries sectors (recreational, subsistence and commercial), the long-term sustainable use of fish resources, as well as the promotion of the economic and social wellbeing of the fishers (Charles, 2001). Consequently, the development of fisheries must be guided by policy, management protocols and institutional arrangements that ensure equitable resource access, biological sustainability and optimisation of economic benefits for both local communities and the national economy.

Policy and planning thus need to be informed by good information on the potential of the resource, the nature of existing fisheries, and the social, environmental and economic issues that shape resource use. Unfortunately, there is almost no information on current harvest rates or the value of various fisheries, and very little on indigenous knowledge and traditional governance arrangements with respect to fish. The data that are available are often not collated, or, if collated, are in grey literature that is not easily accessible, and, because inland fisheries has never been defined as an economic sector in policy, there are several constraints to the usefulness of much of the existing data. Firstly, inland fisheries research has never been well funded in South Africa and most studies that were undertaken on the fisheries potential of impoundments date back to the 1980s, which marked the period just after some of the largest impoundments were constructed, stimulating a brief interest in developing inland fisheries (Cadieux, 1980a; Hamman, 1980; Cochrane, 1983; Jackson et al., 1987). In addition, the freshwater fish research focus has changed over the years from suitability assessments for stocking non-native fishes, through dam building and fisheries development, to a more recent era of biodiversity impact studies. As a result of the paucity of recent literature on inland fisheries, the holistic descriptions of existing fisheries in this report which contextualise the literature presented are to a large extent based on the authors' knowledge of the field.

This literature review, undertaken as part of a larger Water Research Commission (WRC) solicited 'baseline and scoping study on the development and sustainable use of storage dams for inland fisheries and their contribution to rural livelihoods' (WRC Project No. K5/1957//4, WRC, 2011), is the first comprehensive synthesis of existing peer-reviewed and grey literature on inland fisheries in South Africa, and is an important step towards contextualising the resource, as it:

- summarises the state of knowledge on South African inland fisheries;

- identifies potential data sources;

- identifies important knowledge and

- highlights knowledge gaps.

\section{Categorisation of inland fisheries literature}

In the planning process for South African impoundments, the recreational or commercial benefits from associated fisheries development were never considered. As a result, secondary uses of these impoundments for recreational and economic gain are incidental, primarily due to the lack of the incorporation of their potential social and economic importance in the

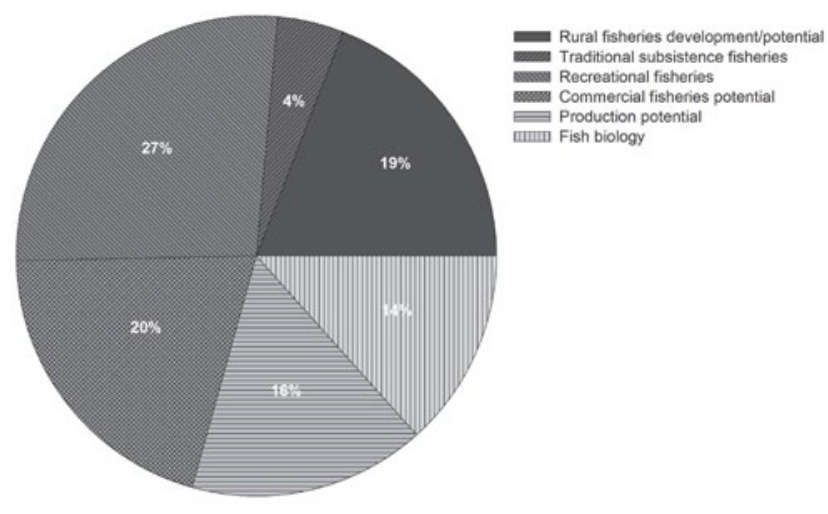

Figure 1

Proportion of published literature concerned with major research topics

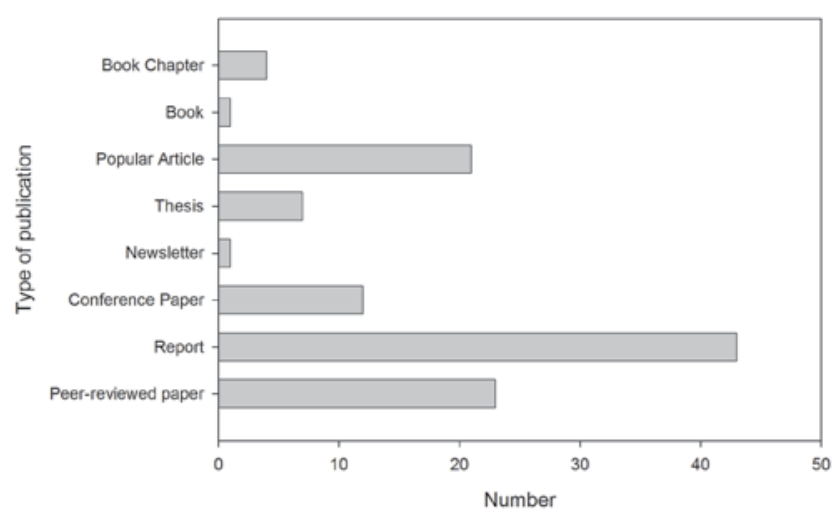

Figure 2

Number and type of publications relating to inland fisheries in South Africa

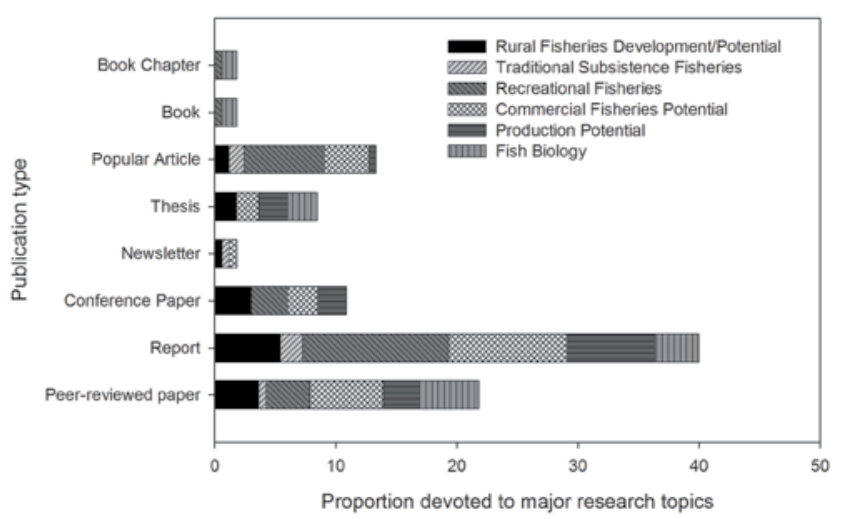

Figure 3

Proportion of different publication types devoted to major research topics in South African inland fisheries

planning process (Du Plessis and Le Roux, 1965). Nonetheless, in subsequent years, a number of studies have been undertaken on a variety of topics related to inland fisheries,including: fish production in different water bodies; rural fisheries development potential; recreational fisheries; traditional fisheries; and valuation studies. A comprehensive literature search using various databases, as well as 'grey data' available from fisheries projects, revealed 173 publications dealing directly with inland fisheries. The nature of these publications is summarised in Figs. 1, 2 and 3, and in Table 1. 


\section{Table 1}

\section{Summary of publications by topic with regards to inland fisheries}

\section{Rural fisheries development/potential}

Andrew et al., 2000; Andrew, 2001; Burton et al., 2002; de Satge, 1978; Duncan-Brown, 1980; Roode, 1978; Rouhani and Andrew, 1998; Rouhani, 2001, 2003, 2004; Rouhani and Davies, 2003; Schramm, 1993; Seti, 2002; van den Berg et al., 1975; van der Waal, 1978, 2000; Weyl et al., 2007.

Traditional subsistence fisheries

Coke and Pott, 1973; Heeg and Breen, 1982; Jubb, 1973; La' Hausse' De' Lalouviere, 1987; Merron et al., 1993; Merron and Weldrick, 1985; Tinley, 1964; van der Waal, 1978.

\section{Recreational fisheries}

Alletson et al., 2004; Anon, 1970; Ashton et al., 1986; Bruwer, 1982; Cadieux, 1980a, 1980b; Clark, 2004; Cochrane, 1987; de Villiers, 1998; du Plessis and le Roux, 1965; Eccles et al., 1983; Ellender et al., 2009, 2010a, 2010b; Granek et al., 2008; Hey, 1926a, 1926b, 1941; Jackson, 1976, 1989; le Roux, 1965; Leibold and van Zyl, 2008; McVeigh, 1978; Nel, 1988; Pott, 1973; Rouhani, 2003, 2004; Rouhani and Davies, 2003; Rouhani et al., 2010; Winker, 2007; Weyl et al., $2010 \mathrm{a}$.

\section{Commercial fisheries potential}

Allanson and Jackson, 1983; Anon, 1948; Eccles et al., 1983; Hamman, 1981; Jackson, 1973, 1974, 1976, 1981a, 1981b; Jubb, 1962; Koekemoer and Steyn, 2005; Nel, 1988; Richardson et al., 2009; Tomasson et al., 1983; Tomasson et al., 1985; van Senus et al., 1992; Weyl et al., 2007, 2010a; Whitehead, 1978.

\section{Production potential}

Allanson and Jackson, 1983; Andrew et al., 2001; Andrew, 2001; Cochrane, 1987; Potts, 2003; Richardson et al., 2009; Rouhani, 2004; Weyl et al., 2010a.

\begin{tabular}{|l|l|}
\hline \multicolumn{2}{|l}{ Research focus by period on inland fisheries related topics } \\
\hline Period & Research focus \\
\hline$<1940$ & Focus on inventory surveys of inland waters and the suitability for the introduction of edible and sport fish \\
\hline $1940-1960$ & The establishment and maintenance of freshwater fish \\
\hline $1961-1970$ & Sport fisheries and quantifying recreational angling. Developing eel fisheries. \\
\hline $1971-1980$ & $\begin{array}{l}\text { Prospects for inland fisheries exploitation and utilising inland waters for rural development in homeland areas. } \\
\text { Angling development }\end{array}$ \\
\hline $1981-1990$ & $\begin{array}{l}\text { Continued emphasis on fisheries potential, although some focus is placed on population dynamics of the target } \\
\text { species. Also increased research on management of inland water bodies. Quantifying angling also emerges. }\end{array}$ \\
\hline $1991-2000$ & Fish population assessments and fisheries potential. Increased emphasis on the management on inland waters. \\
\hline $2001-2010$ & $\begin{array}{l}\text { Focus on fish as a vehicle for rural development and poverty alleviation. Valuation studies. Quantifying inland } \\
\text { fisheries utilisation and in depth studies on fish population dynamics }\end{array}$ \\
\hline
\end{tabular}

\section{Chronological overview of inland fisheries literature}

In this section we categorise the inland fishery literature themes chronologically and track the changing research interests, which tended to mirror societal priorities of the time (Table 2).

\section{Colonial-era fish introductions for recreational fisheries}

Inland fisheries development began with the importation and spread of non-native fishes in South Africa during the $19^{\text {th }}$ century colonial period. The details of the fish introductions are described in De Moor and Bruton (1988) and, more recently, Van Rensburg et al. (2011). Early introductions of alien fishes primarily focused on providing opportunities for recreational angling.

The common carp, Cyprinus carpio, was the first of the popular alien recreational angling species to be introduced into South Africa (De Moor and Bruton, 1988). It was initially introduced in the 1700 s by British colonists for ornamental purposes, and for its believed potential to provide food from South Africa's apparently 'barren' rivers (Anon., 1959; Bruton and Merron, 1985; Bruton and Van As, 1986; De Moor and Bruton, 1988; Skelton, 2001; Van Rensburg et al., 2011). Reports produced by the Inland Fisheries Department, under the Cape Provincial Administration, document that the first official introduction took place in 1896 when C. carpio were imported from England to the Jonkershoek hatchery in the Cape and, in the same year, to the Pirie hatchery in King Williams Town, from Scotland (Anon., 1944; Anon., 1950b). However, De Moor and Bruton (1988) noted that numerous other introductions of $C$. carpio probably occurred during the $19^{\text {th }}$ century. Examples of such 'unofficial' introductions include an article published in The Cape Argus in 1859, which documents the introduction of 6 C. carpio into the Botanical Gardens reservoir in Cape Town by Mr C A Fairbridge, a member of the Cape Legislative Assembly (Anon., 1959b). In addition, an article in The South African Advertiser and Mail refers to the introduction of 3 C. carpio from England by a Mr Ekstein into the pond on his estate (Harrison, 1966b). Following their official introduction to the Cape, C. carpio were distributed to farm dams across South Africa from 1900 (Anon., 1944). After the realisation of their impacts on natural ecosystems, including the introduction of parasites, as well as their ability to drastically alter habitats, stocking activities were ceased and legislation was created in the 1920s in order to halt the further spread of C. carpio (Harrison, 1959; De Moor and Bruton, 1988).

The successful introduction of non-native salmonids into South Africa occurred in the latter part of the $19^{\text {th }}$ century. The 
brown trout, Salmo trutta, a European species, was imported to the Boschfontein Hatchery in Natal in 1890 (Pike, 1980a), and rainbow trout, Oncorhynchus mykiss native to the Pacific coast of North America, were introduced to the Jonkershoek Hatchery in the Cape in 1897 (Manning, 1908; Anon., 1944; Skelton, 2001). Their introduction was a consequence of British colonists' dissatisfaction with the lack of 'suitable' indigenous angling fishes, and the realisation that many of the streams draining mountainous areas in the Cape and Natal would provide suitable trout habitat (Skelton, 2001). Following several importations from European countries, the first hatcheries to successfully produce trout were established at Jonkershoek near Stellenbosch (Anon., 1944), and Pirie near King Williams Town in the Cape Province, in the late 1890s (Harrison, 1954c). Just over 30 years later several other hatcheries had been installed in different parts of South Africa, including Tetworth and Lydenburg hatcheries in Natal and Transvaal, respectively (du Plessis, 1961; Pike, 1980a).

A large proportion of literature on trout fisheries from the colonial period is contained within the Piscator, the journal of the Cape Piscatorial Society (established in 1931), which was first published in 1947. Articles within the journal, as well as other popular publications, include accounts of the first introductions of trout into the country as well as attempts to acclimate and introduce them into various parts of the country (Day, 1932b; Harrison, 1940a; Harrison, 1948b; Anon., 1950a; Harrison, 1951; Harrison, 1953c; Anon., 1961/62; Donnelly, 1965; Harrison, 1972; 1973; Harrison, 1975).

Four centrarchid species, fishes native to North America, were introduced into the country for angling purposes: the largemouth bass, Micropterus salmoides; the smallmouth bass, Micropterus dolomieu; the spotted bass, Micropterus punctulatus and the Florida bass, Micropterus floridanus (De Moor and Bruton, 1988; Skelton and Weyl, 2011). Micropterus salmoides was first introduced in 1928 at the Jonkershoek hatchery in the Cape (Anon., 1944), and was followed by M. dolomieu in 1937 (Anon., 1944; Harrison, 1953a; d; e). These 2 species were introduced into various localities in the province and in 1952 they were stocked in the newly-established Umgeni hatchery in Natal, which undertook their stocking in that province thereafter (Pike, 1980). Micropterus punctulatus was introduced in 1939 into various localities in Natal and the Cape Province (Harrison, 1965/65a), but failed to establish successfully, and its distribution is now limited to only a few localities (Crass, 1964; Smith, 1984; De Moor and Bruton, 1988; Skelton, 2001). In 1980, M. floridanus was introduced to the Umgeni hatchery in Natal for experimental purposes (De Moor and Bruton, 1988 ) and is now present throughout the province (Skelton, 2001). Both M. salmoides and M. dolomieu were introduced widely around the country through the efforts of both anglers and conservation authorities and, as with trout, a large amount of literature on these introductions is available in the Piscator journal as well as other popular publications (Harrison, 1936; 1948b; 1951; Anon., 1952a; Harrison, 1952d; 1952e; 1953a; 1953b; 1954b; Harrison, 1962; 1963a; 1964; 1965a; 1966a; 1967; 1968; Coetzee, 1977; McVeigh, 1979a; Anon., 1980; Anon., 1981; Joubert, 1984; De Moor and Bruton, 1988). Unlike trout fisheries in South Africa - especially those located on reservoirs - which generally require continual stocking as populations cannot reproduce due to adverse ecological conditions, bass fisheries have thrived as a result of these fishes having far wider ecological tolerance limits and the concomitant ability to reproduce in a variety of habitats (Skelton, 2001; Cooke and Philipp, 2009). These predatory fishes prompted many subsequent introductions of non-native fishes as fodder fish and for additional sport angling (De Moor and Bruton, 1988; Skelton, 2001; Van Rensburg et al., 2011).

Early research (pre-1940) therefore concentrated on surveying South African impoundments in order to assess their suitability for stocking a variety of non-native fishes. The earliest report on such suitability is Hey (1926a; 1926b), while subsequent introductions of non-native fishes are comprehensively reviewed by De Moor and Bruton (1988). This focus on suitability of water for sport fishes, and the subsequent importation of a variety of fishes for recreational angling, dominated fisheries development and national stocking programmes until the mid-20 $0^{\text {th }}$ century (Van Rensburg et al., 2011). As a result, inland fisheries were primarily developed for recreational angling (Hey, 1926a; 1926b; McVeigh, 1978; Andrew et al., 2000; Weyl et al., 2007).

\section{Interest in fish as food: 1960s onwards}

An increasing realisation that fisheries could be utilised for commercial purposes, rural development and food security began in the 1960s, and this focus has continued to the present. Several studies investigated the fisheries potential of dams for the establishment of capture fisheries (Jackson, 1973; 1974; 1976; Bruwer and Claasen, 1978; Whitehead, 1978; Koch and Schoonbee, 1980; Hamman, 1981; Jackson, 1981; Bruwer, 1982; Eccles et al., 1983; Allanson and Jackson, 1983; Tómasson, 1983; Tómasson et al., 1983; Tómasson et al., 1985; Cochrane, 1987; Van Senus, 1992; Schramm, 1993; Marshall and Maes, 1994; De Villiers, 1998; 2003; Rouhani and Andrew, 1998; Andrew, 2001; Rouhani, 2001; 2003; 2004; Burton et al., 2002; Potts, 2003; Rouhani and Davies, 2003; Potts et al., 2004; Ellender et al., 2009; Richardson et al., 2009; Weyl et al., 2010a). Research was focused largely on estimating production potential and on the biology of potential fisheries species (De Villiers, 1998; 2003). The role of inland fisheries in potentially providing food received attention as part of South Africa's apartheid homeland development policies of the late 1970s and 1980s (Van den Berg et al., 1975; Roode, 1978; Van der Waal, 1978a; b; 2000; Mabitsela, 1981; Saayman et al., 1983; Schoonbee et al., 1995), as well as from development practitioners (De Satge, 1978; Duncan-Brown, 1980; Taylor and Van der Walt, 1985; Seti, 2002; Allison, 2005). In addition, wider human-ecosystem interaction and livelihood studies have highlighted the role of fisheries in traditional livelihoods. A number of authors have described the floodplain fisheries of the Tshonga people in Maputaland, and analysed the resource governance issues associated with the building of the Pongolapoort Dam, which disrupted the annual flood and associated fishing activities (Tinley, 1964; Coke and Pott, 1971; Jubb, 1973; Heeg and Breen, 1982; LaHausse and DeLalouviere, 1987; Merron et al., 1993; Merron and Weldrick, 1995; Jaganyi et al., 2008). Van der Waal (2000) and Dederen et al. (2001) undertook a sociobiological study of the aquatic resources and their utilisation in an underdeveloped rural region, the Mutshindudi River catchment in Limpopo Province.

From the late 1990 s to the present, literature has increasingly focused on using inland fisheries as vehicles for food security and rural development (Andrew et al., 2000; Van der Waal, 2000; Andrew, 2001), and more recently is moving towards assessing the need for policy (Weyl et al., 2007) and qualifying and quantifying resource use (Van der Waal, 2000; Ellender et al., 2009; 2010a; b). It must, however, be noted that, apart from these very preliminary analyses and site specific 
descriptions on resource use, there is no recent literature available which contextualises inland fisheries with respect to rural development, livelihoods and policy development in South Africa.

\section{Biodiversity concerns}

Growing concerns about the impacts of non-native fish species on freshwater ecosystems began to surface in the $1960 \mathrm{~s}$ and 1970s (Gabie, 1965; Gaigher, 1973; Hey, 1977), and in the 1980s the provincial nature conservation departments ceased breeding and stocking fish into impoundments and streams for recreational angling purposes (Skelton and Davies, 1986; Rouhani and Britz, 2004). A number of studies have documented the impacts of non-native fish introductions, which include predation on native biota, competition for food and space, hybridisation and introduction of parasites and disease (Bruton and Merron, 1985; Bruton and Van As, 1986; Ashton et al., 1986; De Moor and Bruton, 1988; Impson et al., 2007; Lowe et al., 2008; Swartz, 2009; Weyl et al., 2010c; Ellender et al., 2011; Olds et al., 2011; Stadtlander et al., 2011; Van Rensburg et al., 2011; Wassermann et al., 2011a; 2011b). As a result of such impacts, removals of non-native fishes from some invaded areas have been planned in the Western Cape (EnviroFish Africa (Pty) Ltd., 2009). The National Environmental Management: Biodiversity Act (NEM:BA) of 2007 has provided a framework for managing the impacts and beneficial uses of non-native fish species. The primary management tool is the development of a zoning approach whereby permitted uses of non-native species are specified (Swartz, 2009). This legislation will also facilitate and legitimise the formal management of non-native fishes for fisheries.

\section{Current status: South Africa's inland fisheries are data poor}

Overall, there has been little research into inland fisheriesrelated topics, and the research that is available is often outdated and no longer relevant. Of particular concern is the paucity of recent quantitative data on fishery yields, participation and catch rates, as described in papers by Van der Waal (2000) and Ellender et al. (2009; 2010a; b).

\section{Literature on legislation governing inland water resources}

As the research focus and published literature has shifted from the introduction and propagation of non-native fishes, to fisheries development, and more recently the impacts of non-native fishes in South Africa, so too has the legislation regarding the utilisation of inland waters and their resources. Hey (1977) described the history and evolution of nature conservation and associated legislation in South Africa noting that, after the promulgation of the Union of South Africa Act of 1909, which devolved responsibilities for the preservation of fish to the provinces, regulation of fishing activities was largely an administrative function enforced by the South African Police. In the case of the Cape Province, the importation of nonnative species for the purposes of angling was encouraged and permitted in legislature in Act No. 10 of 1867 (Davies, 1986; Ness, 1991), and subsequently provincial governments largely provided financial support for the development and protection of non-native species fisheries (Anon., 1936; Day, 1936; Harrison, 1949; 1957). The formation of the Inland Fisheries
Division (which was later expanded to become the Cape Nature Conservation Department) in the Cape Province in 1942 preceded the first piece of legislation, the Inland Fisheries Ordinance, No. 12 of 1947, which enacted measures pertaining specifically to the protection of aquatic fauna in inland waters, most notably from water pollution (Hey, 1977). As outlined in Harrison (1949), this protection was in the form of proclaimed areas for non-native trout, black bass, perch Perca fluviatilis, and bluegill Lepomis macrochirus, which could only be fished for with an inland fishing licence; no measures enforced the protection of carp, the sale and transportation of which was illegal. This ordinance expanded into the Nature Conservation Ordinance, No. 19 of 1974, which prohibited the transport of non-native fish species while still allowing for the protection of species such as trout through closed seasons, bag and size limits, and tackle restrictions (Hamman, 1986). The ordinance also allowed for the use of nets subject to the possession of a licence issued by the Director of Nature and Environmental Conservation. In Natal, the establishment of the Freshwater Fish Protection Ordinance, No. 9 of 1955 and legislation thereof is discussed in Anon. (1968), with specific reference made to proclaimed trout and non-trout areas, fishing seasons and licence requirements. This was followed by the declaration of the Natal Nature Conservation Ordinance, No. 15 of 1974 , which made no distinction between native and non-native fishes and rendered the use of nets, other than those used for landing fish, illegal. In the Orange Free State, inland fisheries legislation was first outlined in the Nature Conservation Ordinance, No. 8 of 1969, and stipulated regulations including the enforcement of closed seasons, requirement of a licence for angling or netting, permitted fishing areas, and the importation of live fish. Anon. (1970) describes fisheries management and legislation in the Transvaal: the Nature Conservation Division at this time was responsible for implementing fishing licence regulations and using these and other funding sources acquired to develop inland waters for public recreational angling through stocking programmes of native and non-native fishes. The proclamation of the Transvaal Nature Conservation Ordinance, No. 12 of 1983, amalgamated legislation regarding fisheries similar to that implemented in the Orange Free State.

Skelton and Davies (1986) documented the changing attitude of conservation authorities regarding legislation that protected non-native fishes; more specifically, the proposed removal of protective rights assigned to non-native angling species such as trout and bass by the Cape Department of Nature and Environmental Conservation. Hamman (1986) referred to the need for a change in legislation that afforded protection to native species while no longer actively propagating non-native species at state hatcheries for distribution into inland waters. Walmsley and Pike (1989) outlined the legislation surrounding non-native fishes and stressed the need for a revision of policy; this was accompanied by a document describing future guidelines for the promulgation of legislation, which regulated non-native species importations (Anon., 1989). These changes led to cessation of non-native fish production and stocking by the provincial governments and the subsequent closure, 'mothballing' or leasing of most provincial hatcheries, the consequences of which are documented in Rouhani and Britz (2004).

The proclamation of the National Water Act (NWA, 1998) and the National Environmental Management Act (NEMA, 1998) in post-apartheid South Africa, and the resultant governance measures introduced regarding inland fisheries, are discussed in Weyl et al. (2007). The authors note that access 
rights to all water are administered by the Department of Water Affairs (DWAF) while resources, such as fish, are controlled by provincial governments as stipulated in the NEMA, which promotes sustainability, biodiversity, and equitable allocation of resources. Provincial governments reserve the right to administer licences for recreational, subsistence and commercial fishing; however, the paper illustrates the lack of cohesion between government departments and the fact that there is no national lead agent enforcing an overall policy regarding access rights to particular dams and their resources.

NEM:BA was gazetted in 2004 within the fabric outlined in the NEMA. The regulations pertaining to non-native fishes within the NEM:BA, and the contentions of recreational anglers regarding these regulations, have led to official 'position papers' published by various angling bodies such as the Federation of South African Flyfishers (Bainbridge et al., 2005) and the Trout Action Group (TAG), in coordination with the Eastern Cape Flyfishers Club (Fick, 2009). These publications largely object to the NEM:BA. Conversely Roux et al. (2006), in a report that summarises requirements for the conservation of inland water biodiversity, describe the NEM:BA (2004) as well as the NWA (1998) as the 2 most important pieces of legislation concerned with the implementation of conservation measures in South African inland waters.

McCafferty et al. (2010) describe the structural change in inland fisheries governance. Where previously there was no national lead agent in inland fisheries, the mandate for this function came under the auspices of the Department of Agriculture in May 2009, which subsequently became the Department of Agriculture, Forestry and Fisheries (DAFF). The policies of the DAFF, which include food security, economic empowerment and poverty alleviation, now apply to the development of South Africa's inland fisheries resources, the implication being increased impetus to develop fisheries to achieve the above policies within the DAFF mandate.

\section{Literature on South Africa's inland fisheries by sector}

Generally, the development and typical life cycle of an inland fishery begins with an initial emphasis on food production through subsistence utilisation, followed by growing commercial interests (Smith, 1986). As economies develop, subsistence and commercial fisheries give way to recreational fisheries which maximise economic gain through associated industries (Smith, 1986). South African inland fisheries are somewhat anomalous as they have not generally followed this typical evolution, with recreational uses being developed first and subsistence and commercial resource use being recent developments (Andrew et al., 2000; Weyl et al., 2007; Ellender et al., 2009). This can be attributed to several factors including the relatively recent construction of inland impoundments, the associated lack of a fishing tradition in rural communities, apartheid era policies which excluded access to many dams by local communities, as well as the lack of supporting developmental policies.

\section{Recreational fisheries}

'Recreational anglers...utilise the resource primarily for leisure purposes but may sell some of their catch...They generally have permanent employment, use high technology gear consisting of a fibreglass or graphite rod, and a multiplying or spinning reel, and release, consume or sell a portion of their catch.' (Ellender et al., 2009, Table 2, p. 679).
It is estimated that more than 1.5 million people are involved in recreational angling in South Africa (Leibold and Van Zyl, 2008). For the past century, recreational angling has been the dominant activity on South African impoundments (Hey, 1926a; b; Anon., 1970; Anon., 1971; McVeigh, 1978; Andrew et al., 2000; Weyl et al., 2007). It is therefore surprising that this sector remains largely un-quantified and that the only attempts at quantifying recreational angling have been in the Transvaal in the 1960s (LeRoux, 1965) and 1970s (Cadieux, 1980a,b). Besides these studies, only 3 other studies have been undertaken: by Van der Waal (2000) who looked at fishery resources in the Mutshindudi River catchment in Limpopo province; and by Ellender et al. (2009) and Ellender et al. (2010a; b) which described user group dynamics and quantified the harvests from Lake Gariep, South Africa's largest impoundment.

Recreational angling in South Africa remains the major use of inland fisheries; however, since the mid-1990s there appears to have been an increase in the utilisation of inland fisheries by people whose main motivation for using the resource is subsistence (Van der Waal, 2000; Weyl et al., 2007; Ellender et al., 2009).

\section{Subsistence fisheries}

Subsistence users...'live within $15 \mathrm{~km}$ of the lake, use basic transport methods to access the lake (walk, bicycle, and a lift in a vehicle), predominantly use artisanal type gear (e.g. handlines), and are reliant on the resource for food and as a primary or supplementary source of income' (Ellender et al., 2009, Table 2, p. 679).

The emergence of subsistence fisheries on many South African impoundments is a fairly new phenomenon associated with the post-apartheid era. Despite historical development efforts in traditional areas, which included the 1973 appointment of a dedicated fisheries officer with a mandate to encourage harvesting of inland lakes and impoundments, subsistence fisheries failed to develop (Batchelor, 1989). This was attributed largely to the lack of clear policies and associated administrative procedures facilitating the permitting of harvesting (Batchelor, 1989). This situation persists today and Weyl et al. (2007) attributed the low participation in subsistence fisheries to a lack of angling tradition, and the absence of an institutional framework to facilitate managed and sustainable access to the fish resource in many inland waters. Although subsistence fishing has not yet been provided for in the legal reforms of the post-apartheid constitutional democracy, water management authorities now tend to tolerate informal fishing activities by local communities, and in some instances have attempted to promote fishing projects. As a result subsistence use of impoundments is increasing (Weyl et al., 2007; Ellender et al., 2010a; b).

In a case study conducted to assess the fisheries resources in the North West Province, Weyl et al. (2007) reported that, of the 10 dams surveyed, 6 had some sort of subsistence angling activity. On Lake Gariep, subsistence angling dominated the fishery, accounting for $61 \%$ of fishing effort (Ellender et al., 2009). Ellender et al. (2010a) also showed that there were some 450 regular subsistence anglers making use of the resource from adjacent settlements (Ellender et al., 2010b). There are few other descriptions of subsistence angling on impoundments and available reports focus on the Eastern Cape Province (Andrew et al., 2000, Rouhani, 2003). In the Ntenetyana Dam, Alfred Nzo District Municipality, Eastern Cape, approximately 


\begin{tabular}{|c|c|c|c|}
\hline \multicolumn{4}{|c|}{$\begin{array}{l}\text { Table } 3 \\
\text { Summary of available literature and proposed subsistence or commercial fisheries development by water body. } \\
\text { Prov. = Province; EC = Eastern Cape; FS = Free State; KZN = Kwazulu Natal; NW = North West; LP = Limpopo; } \\
\text { GP = Gauteng; MP = Mpumalanga; NC = Northern Cape. }\end{array}$} \\
\hline Waterbody & Prov. & Description & Main References \\
\hline Gariep Dam & FS/EC & $\begin{array}{l}\text { Fisheries assessments and various attempts to } \\
\text { develop fisheries }\end{array}$ & $\begin{array}{l}\text { Hamman, } 1981 \\
\text { Jackson,1981 } \\
\text { Potts et al., } 2004 \\
\text { Winker, 2007 } \\
\text { Ellender et al., } 2010\end{array}$ \\
\hline Darlington Dam & $\mathrm{EC}$ & $\begin{array}{l}\text { Commercial fishery in 1970s and economic } \\
\text { feasibility study conducted in } 2010\end{array}$ & $\begin{array}{l}\text { Whitehead,1978 Jackson, } 1973 \\
\text { Weyl et al., 2010a }\end{array}$ \\
\hline Umtata Dam & $\mathrm{EC}$ & Attempt to develop fishery unsuccessful & $\begin{array}{l}\text { Schramm,1993 } \\
\text { Andrew, } 2001\end{array}$ \\
\hline $\begin{array}{l}\text { Pikoli; Tyefu; Kat River, Laing, } \\
\text { Lubisi, Sinqemeni, } \\
\text { Sheshego, Binfield Park, Dimbaza } \\
\text { and Ndlambe }\end{array}$ & EC & $\begin{array}{l}\text { Attempts with varying success to set up small } \\
\text { scale fisheries } 1999-2000 \text {. }\end{array}$ & $\begin{array}{l}\text { Schramm,1993 } \\
\text { Andrew et al., } 2000 \\
\text { Andrew, } 2001 \\
\text { Potts et al., } 2006 \\
\text { Potts, } 2003\end{array}$ \\
\hline Ntenetyana Dam & $\mathrm{EC}$ & Attempt to set up fishery 2002-2003 & Rouhani, 2003 \\
\hline Cata \& Mnyameni Dam & $\mathrm{EC}$ & Development of recreational fishery & Rouhani et al., 2010 \\
\hline Xonxa Dam & $\mathrm{EC}$ & $\begin{array}{l}\text { Fishery established in } 1980 \text { (unsuccessful); } \\
\text { Fishery potential re-evaluated and quantified } \\
\text { for yellowfish and catfish in } 2010\end{array}$ & $\begin{array}{l}\text { Schramm, } 1993 \\
\text { Duncan-Brown, } 1980 \\
\text { Burton et al., } 2002 \\
\text { Richardson et al., } 2009\end{array}$ \\
\hline Macubeni, Indwe and Nqadu & $\mathrm{EC}$ & $\begin{array}{l}\text { Fishery assessment indicated limited scope for } \\
\text { development of moggel, yellowfish and tilapia. }\end{array}$ & Burton et al., 2002 \\
\hline
\end{tabular}

20-30 fishers from various communities living around the dam were recorded to be angling in the dam using hand lines (Rouhani, 2003). Therefore, although largely undocumented, subsistence use of inland fisheries is likely to be much more widespread than is indicated by the available publications. Recent anecdotal evidence indicates that the subsistence sector is becoming an increasingly important sector in rural livelihoods. Subsistence fishing therefore needs consideration in the long-term planning process for inland fisheries.

\section{Commercial fisheries}

'A commercial fishery is operated by a private individual who is granted access at provincial level to harvest a pre-determined yield from a dam. The enterprise is profit- oriented, striving to minimise production costs and to maximise efficiency in production' (Weyl et al., 2007, p. 3).

Commercial inland fisheries are underdeveloped as a result of a history of limited access to resources, low demand for freshwater fish, the lack of an inland fisheries policy and unclear fisheries management objectives (Weyl et al., 2007). Commercial fishing in the form of single licences is only permitted on a limited scale on a few dams (e.g. Gariep, Bloemhof and Molatedi Dams) (Weyl et al., 2007). Although commercial fisheries remain largely undocumented, historically commercial fisheries operated on a few impoundments including the Kalkfontein Dam, Bloemhof Dam (Orange/Vaal River system) and Darlington Dam (Sundays River system) (Merron and Tómasson, 1984; Potts, 2003). Despite these attempts to develop commercial fisheries on larger impoundments in South Africa the commercial viability of these enterprises has been marginal.

There have been numerous attempts to develop formal small-scale commercial fisheries in rural communities (e.g. Jackson, 1980; Schramm, 1993; Andrew, 2001). The more recent attempts are summarised in Table 3. Unfortunately, few fisheries developed or remained operational after the initial project interventions. The reasons for this lack of success are unclear but have been attributed to: the perceived low value of the resource; lack of a clear guiding policy; little historic involvement in fishing; the limitation of artisanal and subsistence fishing to the former homeland areas under the apartheid era; a cultural resistance to fishing (Andrew, 2001); and the concerns of management authorities that the support of subsistence and commercial use may threaten fish populations (Andrew et al., 2000).

The overriding reason for the lack of development of commercial inland fisheries is probably economic. Recent estimations on the profitability of various commercial fisheries options on Lake Gariep (Potts et al., 2004) and Darlington Dam (Weyl et al., 2010a) found that the low fish price (ZAR 6-10/ $\mathrm{kg}$ ), coupled with the absence of a formal marketing system for inland fish, precluded the economic viability of even small commercial enterprises in these water bodies. In addition, they showed that employment possibilities in commercial fisheries were relatively low, and pointed out that commercial fisheries would most likely result in considerable conflict with other users of the resource. As a result, employment gains from commercial fisheries were likely to be countered by employment losses from tourism at sites where recreational fisheries were well established.

Commercial fisheries assessments and recent developments are summarised in Table 3. Despite such assessments, the only marginally successful, non-subsidised commercial fishery still in operation is located at Bloemhof Dam in the Free State. While catch data from these fisheries are returned to local nature conservation offices and are compiled in internal reports, they are not published in an openly-accessible form. As a result the literature on commercial-level enterprise and catch rate is extremely sparse and comprised of non-standardised or 
even anecdotal data. Whitehead (1978), for example, reports catches of 1 ton per day for 100 days from Darlington Dam; Batchelor (1989) reported that commercial operators in the Free State harvested 469 tons from various dams in 1984; and Andrew et al. (2001) report catches of 3.6 tons in 120 days for Tyefu Dam in the Eastern Cape. Such data lack the information on fishing effort required for any further analyses.

Perhaps most exemplary of the lack of information are the data available for Lake Gariep, South Africa's largest inland water body. The fisheries potential of this dam was recognised as early as 1972, and Hamman (1981) developed a detailed management plan for the fishery. Despite this, commercial fishery development remained dormant until 1992, when a small-scale commercial operation was initiated near the dam wall. This operation failed after some years, but Potts et al. (2004), reported 2 commercial operators on the dam in 2002. To date, the only reported data for any of these formal ventures is a short mention of commercial catches in Potts et al. (2004) which states that 'a total of 4160 fish with a combined mass of $10292 \mathrm{~kg}$ were captured between January 2000 to January 2001 in the gillnet and seine net fishery. The dominant species in terms of number and mass was the common carp and sharptooth catfish, while the other species were caught in very small numbers' (p. 22).

Fisheries assessments depend on the availability of commercial and recreational catch data and compilations of available raw data are an urgent national requirement that are necessary not only for assessments of yield, but also for decision making and economic feasibility analyses.

\section{Managed sport fisheries}

An important, but largely undocumented, element of inland fisheries is the commercial management of private dams and public waters for sport fishing, particularly trout fishing, which forms the basis of a substantial tourism-based local economy in suitable areas of Mpumalanga, KwaZulu-Natal and the Eastern Cape (Hecht and Britz, 1990; Du Preez and Lee, 2010).

The trout fishery and associated economy of Rhodes Village in the Eastern Cape was surveyed by Du Preez and Lee (2010), highlighting the value of recreational fishing as a means of stimulating tourism-based local economic development (LED). A unique inland fishery management system for the local self-sustaining trout population has been created, whereby recreational trout fishing in the rivers and streams in and around Rhodes Village is managed on behalf of riparian landowners by private individuals, the Mosheshs's Ford Angling Club and the Wild Trout Association (WTA). The waters include the upper Kraai, Bell, Kloppershoekspruit, Vlooikraalspruit, Bokspruit, Sterkspruit and Riflespruit. Recreational anglers pay a fee to fish and may also employ the services of a professional angling guide if desired (Du Preez and Lee, 2010).

\section{Literature on the suitability of inland waters for fisheries development}

\section{Fishery productivity yields of South African dams}

South Africa is a water-scarce country and, apart from historic traditional fisheries on the Pongola Floodplain in northern Kwazulu-Natal (Heeg and Breen, 1982) and the Orange River in the Northern Cape (Merron and Weldrick, 1995), opportunities were not widely available for fisheries to develop until the

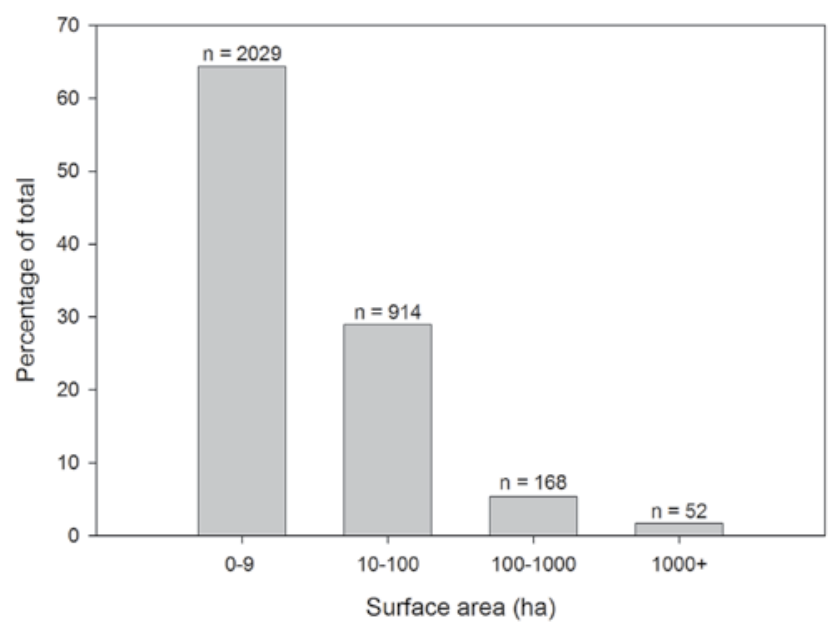

Figure 4

Proportion of South African impoundments categorised by surface area

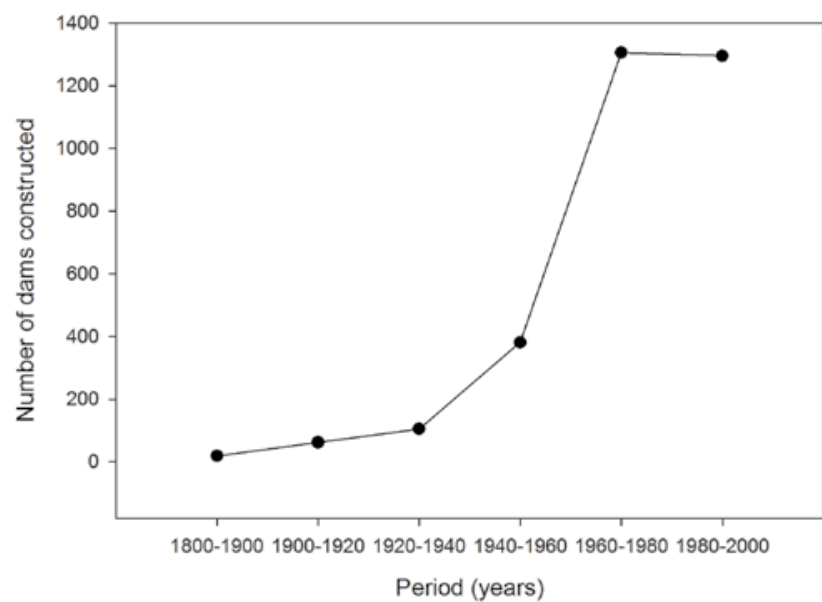

Figure 5

Number of impoundments constructed by 20-year time frame in South Africa between 1800 and 2000. (source data: DWEA, unpublished database)

dam-building era of the $20^{\text {th }}$ century (Andrew et al., 2000). The primary function of these impoundments was to supplement urban and agricultural water supplies, as well as for hydroelectricity. As a result, approximately 3150 impoundments with a surface area $>1.2$ ha have been constructed countrywide (DWAF, 1997) (Fig. 4). During the period from 1800 to 1940 , impoundment numbers increased steadily to approximately 400 , and since then that figure has increased by more than 6 times (Fig. 5). These impoundments have created significant inland water resources amounting to a surface area of more than $3000 \mathrm{~km}^{2}$.

Unfortunately, there are almost no studies on annual harvest rates from inland water bodies in South Africa. Annual catch rates have only been determined for recreational fisheries in Hartebeespoort Dam (Cochrane, 1987), Lake Gariep (Ellender et al., 2010a), and Darlington Dam (Weyl et al., 2010a). In each of these dams estimates are based on 1-year assessments because of the lack of dedicated monitoring surveys (Table 4). An estimate of total inland fisheries production in South Africa of $2300 \mathrm{t} \cdot \mathrm{yr}^{-1}$ is provided in FAO reports on inland fisheries in southern Africa (Van den Bossche and Bernacsek, 1990; Marshall and Maes, 1994). 


\begin{tabular}{|l|l|l|l|l|l|}
\hline \multicolumn{5}{|l|}{ Summary of fish production and calculated annual production per hectare from studies on South } \\
African impoundments
\end{tabular}

It is not known how this estimate was derived, but it most likely includes the $695 \mathrm{t} \cdot \mathrm{yr}^{-1}$ estimated from recreational fishers in Hartebeespoort Dam in the 1980s (Cochrane, 1987) and some of the yields reported by Batchelor (1989).

As a result of this lack of prior fisheries data, direct estimates of fish production cannot be determined, and all assessments of potential fish yield for South Africa are derived from applying empirical relationships to morphological and chemical data. Such relationships, like the Schlesinger and Regier (1982) global temperature-adapted morpho-edaphic index (MEI) model, only give rough indications of potential fish yield. These are summarised in Table 5. A conservative estimate of average fish production of $40 \mathrm{~kg} \cdot \mathrm{ha}^{-1}$, based on documented studies, indicates that the potential fish production from these water bodies could potentially yield 1000 to $2000 \mathrm{t} \cdot \mathrm{yr}^{-1}$. Allocations between recreational, subsistence and commercial fisheries are likely to be problematic, as there is limited published information available to decision makers regarding the value of extant fisheries and the multiple user groups that may access water resources, leading to uncertainty regarding potential conflict areas between these sectors (McCafferty et al., 2010).

\section{Potential fishery production from small water bodies}

Fisheries in the southern African region, an area encompassing those countries belonging to the Southern African Development Community (SADC), are primarily located on major lakes (e.g. Lakes Tanganyika and Malawi) or in large man-made dams (e.g. Kariba) (Marshall and Maes, 1994; Weyl et al., 2010b). In many cases, the potential for further development of these fisheries is limited and some are already considered to be maximally- or overexploited (Marshall and Maes, 1994; Weyl et al., 2010b). This is not the case for smaller reservoirs constructed for water supply purposes, which have significant fisheries potential but which are largely undeveloped (Marshall and Maes, 1994).
Unlike other countries in the SADC, which have significant amounts of fisheries data, South Africa did not join the SADC until 1994 and therefore data on small water bodies presented in the Marshall and Maes (1994) review for this country are not comprehensive. That which is presented highlights South Africa's limited natural lake area, large number of reservoirs, and fish yield, which, in contrast to other SADC countries, is largely accounted for by recreational anglers. While data deficient, the report does provide an estimate of total fish production in South Africa of $2300 \mathrm{t} \cdot \mathrm{yr}^{-1}$, as mentioned earlier, and a map illustrating all of the South African impoundments is also included in the report. Importantly, the review also makes mention of the potential that stock enhancement may have in improving the productivity of small reservoirs in the region and highlights the introduction of non-native species in South Africa as an example.

\section{Attempted interventions to establish fisheries}

Attempts to establish capture fisheries in inland waters date back to the 1970s. Few have been successful and, while there is some literature on the establishment of some fisheries (see Table 3), no studies exist that evaluate the success rate or the current number of functioning enterprises. Some of the betterdocumented case studies are summarised below.

Stock enhancement using mullet in the Eastern Cape In the late 1970s and early 1980s a number of Eastern Cape impoundments were stocked with 2 species of mullet: Myxus capensis; and Mugil cephalus (Bok, 1983). The fingerlings were wild caught in Eastern Cape estuaries and subsequently stocked into impoundments to provide opportunities for the development of gillnet fisheries. The stocking was aimed at enhancing the fisheries potential of impoundments with mullets, which were commercially more viable than the resident moggel Labeo umbratus and C. carpio (Bok, 1983). While 
growth rates and catches were favourable, with yields of up to $500 \mathrm{~kg} \cdot \mathrm{ha}^{-1}$, the unpredictable recruitment of wild-caught fry proved to be a significant bottleneck and constraint to future development of this fishery (Bok, 1983).

\section{Fisheries development in rural areas}

During the 1970s and 1980s there was a movement toward promoting the use of freshwater fish in impoundments, through stocking and training programmes in the former homeland areas, and fisheries sections were active in the authorities of Transkei, Ciskei, KwaZulu, Qwaqwa, Venda, Lebowa, Gazankulu and Bophuthatswana (Van den Berg et al., 1975; Roode, 1978; Van der Waal, 1978a; b; 2000; Mabitsela, 1981; Saayman et al., 1983; Schoonbee et al., 1995; Andrew et al., 2000). A fishery for wild fish stocks was promoted for a short period in 1979/80 on Xonxa Dam in the Glen Grey District (Duncan-Brown, 1980). These homeland authorities promoted commercial angling from dams, and ran hatcheries to produce fingerlings for stocking purposes (Andrew et al., 2000; Rouhani and Britz, 2004). There is little evidence suggesting that these efforts resulted in significant benefits for the communities involved (Andrew et al., 2000).

In post-apartheid South Africa, inland fishery projects have been undertaken in a few locations. In the Eastern Cape Province, a community-driven fisheries project was undertaken on the Great Fish River, as well as in 2 small impoundments. The fishery in the Fish River Valley was shown to contribute to food security and income generation for the communities living in that area (Andrew et al., 2000). The Rural Fisheries Programme (RFP) of the Department of Ichthyology and Fisheries Science of Rhodes University was commissioned by the Alfred Nzo District Municipality to survey Ntenetyana Dam, to determine its fisheries potential. There was an existent subsistence fishery, and management recommendations indicated that fishery activities could be expanded such that a community-based, small-scale fishery was developed incorporating hook-and-line and seine-netting subsistence practices, as well as a recreational fishery component (Rouhani, 2003). The current status of these fisheries has, however, never been evaluated.

Lake Gariep was constructed in 1972 and periodic attempts have been made to harvest fish commercially since 1992 (Potts et al., 2004). In 2004, the Free State Department of Economic Affairs, Environment and Tourism (DEAET) provided support to the Venterstad Community Fisheries Project (VCFP), which aimed to provide poverty relief to historically-disadvantaged communities in Venterstad and Oviston, through facilitating their access to the fishery in specific areas of the lake. An experimental fishing permit was issued by DEAET to allow for the harvesting of an initial quota of $50 \mathrm{t} \cdot \mathrm{yr}^{-1}$ of C. carpio, sharptooth catfish Clarias gariepinus and mudfish Labeo capensis. The permit was granted specifically for hook-and-line angling (Potts et al., 2004). The project shut down after a short running period due to bad planning and management, and a lack of consultation and local knowledge (Potts et al., 2004). Currently the fish resource is used only by subsistence and recreational anglers (Ellender et al., 2009).

The commercial fishery development attempts in Darlington Dam, Eastern Cape, are summarised by Weyl et al. (2010). In 1978, a fishery operation was initiated in Darlington Dam which comprised a team of 5 fishermen equipped with gillnets and a small boat. The operation provided gutted $L$. umbratus and $C$. carpio to markets in both Grahamstown and Uitenhage. Catch rates were high and it was reported that $1 \mathrm{t} \cdot \mathrm{d}^{-1}$ could be harvested. While the operation was profitable, the operation ceased after a year due to the withdrawal of the manager. Subsequently, attempts were made to develop various gillnet fisheries based on these species. In the 1980s, a gillnet fishery that salted and dried fish was set up under the management of Mr Tiko Hirsch. During this time the dam was also stocked with mullet to supplement the fishery. Due to economic reasons this commercial operator moved to the Free State to begin operations on Bloemhof Dam. No further attempts have been made to develop a commercial fishery on the dam. There was, however, some reported conflict between this fishery and recreational angling, pertaining to competition for the resource and pollution resulting from fish processing on the lakeshore (Weyl et al., 2010a).

\section{Biological survey information with fisheries management recommendations}

There is a paucity of available literature investigating the biological sustainability of harvesting fish populations in South African impoundments. Surveys on the biology and management of fish populations are limited to 3 Transkei reservoirs, Xonxa, Lubisi and Umtata (Schramm, 1993; Richardson et al., 2009); 2 impoundments on the Orange River system in the Free State, Lake Gariep and Lake Van der Kloof (Hamman, 1981; Allanson and Jackson, 1983; Tómasson, 1983; Tómasson et al., 1985; Potts et al., 2004; Ellender et al., 2009; 2010a; b); 5 small impoundments in the Eastern Cape (Potts, 2003; Potts et al., 2006); Hartbeespoort Dam on the Crocodile- and Magalies River systems in the North West Province (Koekemoer and Steyn, 2005); Darlington Dam on the Sundays River system in the Eastern Cape (Weyl et al., 2010a); and the growth and survival of 2 mullet species (M. capensis, M. cephalus) stocked as wild-caught juvenile fish into impoundments in the Eastern Cape (Bok, 1983).

On Lake Gariep, post-impoundment surveys were conducted over an 8-year period on fish population dynamics and production potential of largemouth yellowfish Labeobarbus kimberleyensis, smallmouth yellowfish Labeobarbus aeneus, L. capensis, L. umbratus, C. gariepinus and C. carpio, in order to develop a fisheries management plan (Hamman, 1981). The study concluded that a commercial gillnet fishery could be implemented and an annual catch of 886 tons (multi-species) could be harvested. Cyprinus carpio was considered as the species with the largest harvest potential.

In the period between 1978 and 1983, concurrent studies were undertaken on the limnology and fisheries potential of Lake Van der Kloof (previously Lake Le Roux) (Allanson and Jackson, 1983; Tómasson, 1983; Tómasson et.al., 1983; Tómasson, 1985). It was concluded that the physical characteristics of the lake inhibited the harvest potential and that approximately 150-200 tons could be harvested annually. The targeted species would predominantly be L capensis and L. aeneus, but variable annual recruitment and growth were cited as inhibiting extensive harvest potential (Tómasson, 1983; Tómasson et al., 1983).

Schramm (1993) conducted gillnet surveys to investigate the fisheries potential of 3 Transkei reservoirs (Xonxa, Lubisi, Umtata) and documented the reproductive biology of the fish populations to determine their sustainability. Only Xonxa reservoir displayed favourable catch rates for the establishment of a fishery. The biological characteristics of L. aeneus, upon which the fishery would be based, were also favourable 
Table 5

Summary of potential yields and recommended harvest rates per hectare from studies on South African impoundments

\begin{tabular}{|c|c|c|c|c|c|c|c|}
\hline Province & Waterbody & \begin{tabular}{|l} 
Surface \\
Area (ha)
\end{tabular} & $\begin{array}{l}\text { Fish Production } \\
\text { Indicator }\end{array}$ & Species & \begin{tabular}{|l|} 
Actual \\
Estimate
\end{tabular} & \begin{tabular}{|l|} 
Calculated \\
minimum \\
yield/ha
\end{tabular} & Reference \\
\hline \multirow{7}{*}{$\begin{array}{l}\text { Eastern } \\
\text { Cape }\end{array}$} & \multirow[t]{7}{*}{ Darlington Dam } & \multirow[t]{7}{*}{4000} & Potential yield & C. gariepinus & $22-98 \mathrm{t}^{\cdot} \mathrm{yr}^{-1}$ & 6 & \multirow{7}{*}{$\begin{array}{l}\text { Weyl et al., } \\
\text { 2010a }\end{array}$} \\
\hline & & & Potential yield & O. mossambicus & $2-9 \mathrm{t} \cdot \mathrm{yr}^{-1}$ & 1 & \\
\hline & & & Potential yield & C. carpio & $3-12 t \cdot \mathrm{yr}^{-1}$ & 1 & \\
\hline & & & Potential yield & L. aeneus & $3-15 \mathrm{t} \cdot \mathrm{yr}^{-1}$ & 1 & \\
\hline & & & Potential yield & L. capensis & $6-26 t^{\prime} \cdot \mathrm{yr}^{-1}$ & 2 & \\
\hline & & & Potential yield & L. umbratus & $67-299 \mathrm{t} \cdot \mathrm{yr}^{-1}$ & 17 & \\
\hline & & & Recreational harvest & All species & $104-460 \mathrm{t} \cdot \mathrm{yr}^{-1}$ & 26 & \\
\hline \multirow{5}{*}{$\begin{array}{l}\text { Eastern } \\
\text { Cape }\end{array}$} & Dimbaza Dam & 46.2 & Potential yield & L. umbratus & $2.16 \mathrm{t}^{-} \mathrm{yr}^{-1}$ & 47 & \multirow[t]{5}{*}{ Potts, 2003} \\
\hline & Kat River Dam & 214 & Potential yield & L. umbratus & $0.17 \mathrm{t}^{\mathrm{y}} \mathrm{yr}^{-1}$ & 8 & \\
\hline & Laing Dam & 211 & Potential yield & L. umbratus & $1.73 \mathrm{t} \cdot \mathrm{yr}^{-1}$ & 8 & \\
\hline & Ndlambe Dam & 16.2 & Potential yield & L. umbratus & $1.18 \mathrm{t} \cdot \mathrm{yr}^{-1}$ & 73 & \\
\hline & Sinqemeni Dam & 9.3 & Potential yield & L. umbratus & $1.62 \mathrm{t}^{\mathrm{y}} \cdot \mathrm{rr}^{-1}$ & 174 & \\
\hline \multirow{3}{*}{$\begin{array}{l}\text { Eastern } \\
\text { Cape }\end{array}$} & \multirow[t]{3}{*}{ Xonxa Dam } & \multirow[t]{3}{*}{1450} & Potential yield & L. aeneus & $23 \mathrm{t} \cdot \mathrm{yr}^{-1}$ & 16 & \multirow{3}{*}{$\begin{array}{l}\text { Richardson et } \\
\text { al., } 2009\end{array}$} \\
\hline & & & Potential yield & C. gariepinus & $4 \mathrm{t} \cdot \mathrm{yr}^{-1}$ & 3 & \\
\hline & & & Potential yield & All species & $27-139 \mathrm{t} \cdot \mathrm{yr}^{-1}$ & 19 & \\
\hline \multirow{2}{*}{$\begin{array}{l}\text { Free State/ } \\
\mathrm{NC}\end{array}$} & \multirow[t]{2}{*}{ Van der Kloof Dam } & \multirow[t]{2}{*}{13340} & Recreational harvest & L. capensis & $75-100 t \cdot \mathrm{yr}^{-1}$ & 6 & \multirow{2}{*}{$\begin{array}{l}\text { Allanson and } \\
\text { Jackson, } 1983\end{array}$} \\
\hline & & & Recreational harvest & L. aeneus & $75-100 \mathrm{t} \cdot \mathrm{yr}^{-1}$ & 6 & \\
\hline \multirow[t]{9}{*}{ North West } & Hartbeespoort Dam & 2000 & Potential yield & All species & $200-300 \mathrm{t} \cdot \mathrm{yr}^{-1}$ & 100 & \multirow{9}{*}{$\begin{array}{l}\text { Koekemoer } \\
\text { and Steyn, } \\
2005 \\
\text { Rouhani, } 2004\end{array}$} \\
\hline & Madikwe Dam & 431.8 & Recreational harvest & C. gariepinus & $5.5 \mathrm{t} \cdot \mathrm{yr}^{-1}$ & 13 & \\
\hline & \multirow[t]{2}{*}{ Molatedi Dam } & & Recreational harvest & O. mossambicus & $4 \mathrm{t} \cdot \mathrm{yr}^{-1}$ & 5 & \\
\hline & & & Recreational harvest & C. gariepinus & $9.5 \mathrm{t} \cdot \mathrm{yr}^{-1}$ & 13 & \\
\hline & Ngotwane Dam & 401.3 & Recreational harvest & C. gariepinus & $8 \mathrm{t} \cdot \mathrm{yr}^{-1}$ & 20 & \\
\hline & \multirow[t]{2}{*}{ Roodekopjes Dam } & \multirow[t]{2}{*}{1571} & Recreational harvest & O. mossambicus & $1 \mathrm{t}^{\mathrm{y}} \cdot \mathrm{yr}^{-1}$ & 1 & \\
\hline & & & & C. gariepinus & $4 \mathrm{t}^{\cdot} \cdot \mathrm{yr}^{-1}$ & 3 & \\
\hline & \multirow[t]{2}{*}{ Vaalkop Dam } & \multirow[t]{2}{*}{1110} & Recreational harvest & C. gariepinus & $5.5 \mathrm{t} \cdot \mathrm{yr}^{-1}$ & 5 & \\
\hline & & & Recreational harvest & O. mossambicus & $2 \mathrm{t} \cdot \mathrm{yr}^{-1}$ & 2 & \\
\hline
\end{tabular}

for sustainable exploitation. The fisheries potential of Xonxa reservoir was revisited by Richardson et al. (2009), and the biology of L. aeneus and C. gariepinus were investigated to provide input parameters for stock assessment models upon which fisheries development and management could be based. The study indicated that 2 sustainable fisheries could be developed: a gillnet fishery for L. aeneus $(60 \mathrm{~mm}$ stretched mesh), which could harvest $23 \mathrm{t} \cdot \mathrm{y}^{-1}$; and a longline fishery for C. gariepinus yielding a maximum of $4 \mathrm{t} \cdot \mathrm{y}^{-1}$ (Richardson et al., 2009).

The life histories and fisheries potential of populations of L. umbratus from 5 small Eastern Cape reservoirs (Katriver, Laing, Sinqemeni, Ndlambe and Dimbaza) were investigated (Potts, 2003; Potts et al., 2006). The research concluded that L. umbratus populations in small, shallow, slightly-enriched reservoirs would be more suitable for exploitation, as these populations were faster growing and were therefore more likely to sustain fishing pressure than populations from more oligotrophic reservoirs (Potts, 2003; Potts et al., 2006).

Koekemoer and Steyn (2005) conducted a survey of the fish community of Hartbeespoort Dam. Based on the catch composition in experimental gillnets, they concluded that the eutrophic state of the dam favoured a fish community dominated by benthic feeding C. gariepinus and C. carpio. The authors hypothesised that the removal (through harvesting) of 200-300 tons of these 2 species would help restore zooplankton and macrobenthos communities and shift the fish community towards one dominated by Mozambique tilapia Oreochromis mossambicus. Harvesting was to be undertaken by a community fishery project using mainly gillnets. Unfortunately, no subsequently published data are available on harvests or the response of fish communities to harvesting.

A study on the response of $L$. umbratus, C. carpio and $C$. gariepinus to current recreational angling, as well as 2 proposed commercial level fisheries (longline and gillnet fishery), was undertaken on Darlington Dam (Weyl et al., 2010a). Stock assessment models indicated that a $100 \mathrm{~mm}$ mesh size gillnet fishery was feasible, although initial harvest levels for a gillnet fishery should be conservative and annual harvests should not exceed 60 tons until the full impact on the stock is determined (Weyl et al., 2010a). It was estimated that the current recreational fishery targeting C. gariepinus on Darlington Dam could increase its catch 5 -fold before the spawner biomass would be reduced to critical levels. From the biological and experimental fishing (longlines) information obtained for $C$. gariepinus, a commercial fishery could harvest the species sustainably (Weyl et al., 2010a).

From the aforementioned examples, it is evident that few biological studies have been undertaken to determine the biological sustainability of harvesting fish from South African impoundments. Without information on the biology of species targeted by fisheries, development is severely hampered, as the life-history characteristics of a species directly influence their vulnerability to exploitation, and consequently also the economic feasibility of the fishery. 


\section{Value of inland fisheries}

South African inland fisheries are largely overlooked as a 'beneficial use' of water in the literature on water resource governance and management. Studies such as Weyl et al. (2007) on fisheries in the North West Province, and the valuations of recreational fisheries by Leibold and Van Zyl (2008), Brand et al. (2009) and Du Preez and Lee (2010), provide an initial insight into the value of the current inland fisheries.

What is evident is that, while commercial fisheries have a long history of failure in South African inland waters, the recreational value of these resources is considerable. A nonpeer reviewed study on the value of recreational fisheries in South Africa, commissioned by the South African Deep Sea Angling Association (SADSAA) in 2007, estimated that the average annual expenditure by anglers affiliated to angling clubs was ZAR7 500 angler $^{-1} \cdot \mathrm{yr}^{-1}$ and that the economic impact of these anglers, who represent about $10 \%$ of participants, was estimated at ZAR900 million.yr ${ }^{-1}$ (Leibold and Van Zyl, 2008). While extrapolations of this value for the unaffiliated anglers cannot be made with any confidence, the report demonstrates the economic contribution that the recreational sector makes to the national economy.

Brand et al. (2009) valued yellowfish-dependent recreational angling on the Vaal River to be in the region of ZAR 133 million per season. Du Preez and Lee's (2010) survey of the economic value of the trout sport fishery to Rhodes Village in the Eastern Cape showed that trout fishing was an important contributor to local tourism, generating ZAR 13.5 million and employing 85 people in a rural village of 600 people, where only $15 \%$ of the population were formally employed. Average expenditure was ZAR 5052 per angler per trip, which averaged 5 days. The study was conducted concurrently to the development of the alien species zoning regulations contained within the NEM:BA, and estimated the potential loss in jobs and revenue to Rhodes Village if trout were to be eradicated from the local rivers and dams. The angler survey revealed that 39 angling-related jobs and ZAR 5.5 million annual income would be lost if trout were to be eradicated from the local rivers.

From a subsistence-use perspective, Ellender et al. (2009; 2010 b) showed that at least $59 \%$ of the total angling effort in a portion of Gariep Dam was exerted by a minimum of 448 regular subsistence anglers. They cautioned that future development of commercial fisheries could create competition for resources and market with the extant subsistence sector. As a result subsistence users of inland fisheries in South Africa require formal recognition so that their rights to resource use are secured and their livelihoods protected.

The implementation of sustainable development requires that choices regarding environmental resource use, biodiversity conservation and livelihoods need to be informed by evaluations of ecosystem goods and services. These studies exemplify the need for future fisheries development to be guided by sound information that minimises the negative economic impacts of future fisheries development and secures the livelihoods of subsistence users.

\section{Conclusions}

While inland fisheries in South Africa undoubtedly contribute to South Africa's economy through the economic impact of recreational fisheries, and provide food security to rural people living in their vicinity, there is a general lack of literature upon which a national inland fisheries strategy can be based.
The available literature is temporally disjunct, site specific and predominantly not peer-reviewed.

Apart from a recent paper which describes the fisheries sectors using Lake Gariep (Ellender et al., 2009), there is no recent description of any of the inland fisheries operating in South Africa. Proper descriptions of each sector incorporating data on harvest rates, utilisation patterns and economic contributions are needed urgently.

Unfortunately, inland fisheries are not routinely monitored. Membership in formal recreational angling organisations are reported to be in the region of 150000 people (Leibold and Van Zyl, 2008). Subsistence- and recreational use by non-affiliated anglers is likely to be even greater. This lack of knowledge obviously constrains the decision-making process, because there are no data against which to gauge the impact of interventions such as the development of a commercial fishery. On Lake Gariep, for example, a commercial fishery employing, at most, 10 people would most likely negatively impact on the livelihoods of 448 subsistence users (Ellender et al., 2010a; b).

Catch rates and harvests are only available for four case studies (Cochrane, 1983; Van der Waal, 2000; Ellender et al., 2010; Weyl et al., 2010a). This is a major bottleneck in assessing the potential of inland fisheries because the de facto open access nature of inland fisheries to recreational and subsistence users (Weyl et al., 2007) may already have led to unsustainable harvest rates and over-fishing in some dams. Globally, for example, there is increasing recognition that the impact of recreational angling (fishing with a rod, line and hook) on fish stocks is as significant as that of many commercial fisheries (Cooke and Cowx, 2004; Arlinghaus and Cooke, 2005). Catch data are therefore urgently required because without such data it is largely impossible to determine whether additional fisheries could or should be developed. As a direct result of the lack of catch data, all estimates of potential yield and production in the country are based on applying empirical relationships to morphological and chemical data for water bodies. While these relationships have been shown to be more than incidental (Ryder, 1965), they are, at best, only very rough indications of potential yield. Some data are, however, available. Recreational anglers have good competition data and nature conservation authorities keep records on catches and licence allocations. A collation of such data in a centralised database would provide important planning information for a variety of different impoundments.

There have been numerous attempts to develop fisheries in rural areas. Documented evidence shows that almost all have failed. Others have never been reassessed after the initial development and so there are no actual data upon which an analysis of the success or failure of interventions could be based.

Economic assessments of inland fisheries are also very few. Those that have been undertaken, however, indicate that recreational fisheries contribute significantly to provincial and national economies (Cadieux, 1980a; Brand et al., 2009; Du Preez and Lee, 2010; Leibold and Van Zyl, 2010). This lack of information on the value of fisheries is a global problem, and Cowx and Gerdeaux (2004) point out that fisheries tend to be poorly- or under-valued in multiple aquatic resource user scenarios. Further valuation studies, such as that of Du Preez and Lee (2010) showing the benefits of recreational fishing to rural communities, are required if informed choices are to be made regarding the promotion of inland fisheries for rural livelihood development.

Additional information limitations include information on inland fisheries governance, fishery governance systems, 
licensing, resource allocations and policy. User conflicts, particularly between recreational and subsistence and commercia fishers, are mentioned in some publications (Weyl et al., 2007; Weyl et al., 2010a) and exist in many fisheries. However, there is little documented evidence on these conflicts, understanding the causes behind them is however essential for fisheries development and policy formulation.

The present literature survey reveals an urgent need for research covering the biological, social, economic and governance aspects, if inland fisheries are to be developed in a rational and sustainable manner which promotes South Africa's national policy goals.

\section{Acknowledgements}

This paper was developed as part of a larger Water Research Commission (WRC) solicited and funded 'baseline and scoping study on the development and sustainable use of storage dams for inland fisheries and their contribution to rural livelihoods' (WRC Project No. K5/1957/4). This research was also financially supported by the National Research Foundation (NRF) of South Africa. We thank 2 anonymous referees for their valuable comments.

\section{References}

ARLINGHAUS R and COOKE SJ (2005) Global impact of recreational fisheries. Science 307 (5715) 1561-1563.

ALLANSON BR and JACKSON PBN (eds.) (1983) Limnology and Fisheries Potential of Lake le Roux. South African National Scientific Programmes Report No. 77. CSIR, Pretoria. 182 pp.

ALLETSON J, ROUHANI QA and JONES CLW (2004) The potential for a community-based angler guiding service on the Pongolapoort Dam in northern Kwazulu-Natal. Rural Fisheries Programme, Department of Ichthyology and Fisheries Science, Rhodes University. $47 \mathrm{pp}$.

ALLISON EH (2005) The fisheries sector, livelihoods and poverty reduction in Eastern and Southern Africa. In: Ellis F and Freeman HA (eds.) Rural Livelihoods and Poverty Reduction Policies. Routledge Publishers, London. 256-273.

ALLISON EH, MVULA PM and ELLIS F (2002) Competing agendas in the development and management of fisheries in Lake Malawi. In: Geheb K and Sarch MT (eds.) Africa's Inland Fisheries: The Management Challenge. Fountain Books, Kampala. 49-88.

ANDREW TG (2001) Final Report on the Activities of the Rural Fisheries Programme, 1997-2000. Rural Fisheries Programme, Department of Ichthyology and Fisheries Science, Rhodes University. $155 \mathrm{pp}$.

ANDREW TG, ROUHANI QA and SETI S (2000) Can small-scale fisheries contribute to poverty alleviation in traditionally nonangling communities in South Africa? Afr. J. Aquat. Sci. 25 49-55

ANON. (1936) Regulations governing fishing in the inland waters of Natal, Union of South Africa. Natal Provincial Administration. $40 \mathrm{pp}$.

ANON. (1944) Report No. 1. Inland Fisheries Department, Cape Provincial Administration. 1-5.

ANON. (1948) Crops from inland waters. Veld Trust News (January 1948) 6-9.

ANON. (1950a) Trout pioneering in the Eastern Cape. No. 3.The debut of A N Stenning, 1896. Piscator 16 117-120.

ANON. (1950b) Report No. 7. Inland Fisheries Department, Cape Provincial Adminstration. 26-27.

ANON. (1952a) Smallmouth bass in the Umtata River. Piscator 24115. ANON. (1959b) Importation of carp. Piscator 4647.

ANON. (1961/62) Trout airlifted to the upper Elandspad. Piscator $\mathbf{5 3}$ 95-99.

ANON. (1968) The Sportsmans Guide to the Hunting and Fishing Laws of Natal. Natal Parks, Game and Fish Preservation Board. $1-16$.
ANON. (1970) Transvaal fisheries management. Fauna \& Flora 20 6-7. ANON. (1971) Licence sales are up. Fauna \& Flora 2112.

ANON. (1980) Florida bass put in farm dams near Franklin. Kokstad Advertiser (December 1980) 11.

ANON. (1981) Florida bass breed in Natal. Tight Lines 22 (2) 10. ANON. (1984) Ilhati Nets: A Ciskei net mounting industry. $6 \mathrm{pp}$.

ANON. (1989) Guidelines for legislation and control of the importation of aquatic animals into southern Africa. Foundation for Research Development Ecosystems Programmes Occasional Report Series. FRD, Pretoria, South Africa. 97-100.

ASHTON PJ, APPLETON CC and JACKSON PBN (1986) Ecological impacts and economic consequences of alien or invasive organisms in southern African aquatic ecosystems. In: MacDonald IAW, Kruger FJ and Ferrar AA (eds.).The Ecology and Management of Biological Invasions in Southern Africa. Oxford University Press, Cape Town. 247-260.

BAINBRIDGE B, DAVIES MTT, ALLETSON J and LAX I (2005) Trout Position Paper. Federation of South African Flyfishers. 20 pp.

BATCHELOR GR (1974) An ecological investigation of the Doorndraai Dam, Sterk River, Transvaal, with special reference to fish management. M.Sc. Thesis, Rand Afrikaans University, South Africa. $131 \mathrm{pp}$.

BATCHELOR A (1988) The Department of Development Aid and Fisheries Development. Paper presented at $20^{\text {th }}$ regular meeting of the Southern African Regional Commission for the Conservation and Utilisation of Soil (SARCCUS) Standing Committee for Animal Production, 22-24 November 1988, Gaborone, Botswana. $10 \mathrm{pp}$.

BOK A (1980) Freshwater mullet in the Eastern Cape. The Eastern Cape Naturalist 69 12-14.

BOK A (1983) The demography, breeding biology and management of 2 mullet species (Pisces: Mugilidae) in the Eastern Cape, South Africa. Ph.D. Thesis, Rhodes University, South Africa. 268 pp.

BRAND M, MAINA J, MANDER M and O'BRIEN G (2009) Characterisation of the social and economic value of the use and associated conservation of the yellowfishes in the Vaal River. WRC Report No. KV 226/09. Water Research Commission, Pretoria. 49 pp.

BRITZ PJ, LEE B and BOTES L (2009) AISA 2009 Aquaculture Benchmarking Survey: Primary Production and Markets. AISA report produced by Enviro-Fish Africa (Pty.) Ltd. 117 pp.

BRUTON MN and MERRON SV (1985) Alien and Translocated Animals in Southern Africa: A General Introduction, Checklist and Bibliography. South African National Scientific Programmes Report No. 113. CSIR, Pretoria. 71 pp.

BRUTON MN and VAN AS JG (1986) Faunal invasions of aquatic ecosystems in southern Africa, with suggestions for their management. In: Macdonald IAW, Kruger FJ and Ferrar AA (eds.) The Ecology and Management of Biological Invasions in Southern Africa. Oxford University Press, Cape Town. 47-61.

BRUWER CA (1982) Multi-purpose use of an eutrophic South African man-made reservoir. Can. Water Resour. J. 7 (2) 238-254.

BRUWER CA and CLAASSENS GCD (1978) Die vispotentiaal van Suid-Afrikaanse damme. South African Association for the Advancement of Science, Biennial Congress, Stellenbosch. The Future and it's Challenges 1308-320.

BURTON S, CHALMERS R, COWLEY P, FIELDING P, JONES C, POTTS W, ROUHANI Q, SONGONGO M, TIMMERMANS $\mathrm{H}$, VINE N and WOOD A (2002) A report on the feasibility of inland fisheries and oyster farming in the Emalahlani and Mbashe Municipalities respectively. Rural Fisheries Programme, Department of Ichthyology and Fisheries Science, Rhodes University. 137 pp.

CADIEUX JJ (1980a) Freshwater angling in the Transvaal - its environmental and economic impact. S. Afr. J. Sci. 76 492-493.

CADIEUX JJ (1980b) Angling in the Transvaal. Fauna and Flora Transvaal $\mathbf{3 8} 16$

CHARLES A (2001) Sustainable Fishery Systems. Fish and Aquatic Resources Series 5. Blackwell Science Ltd., Oxford. 370 pp.

CLARK JR (2004) The yellowfish fishery on the Upper Komati: A landowners perspective. Proc. $8^{\text {th }}$ Yellowfish Working Group Conf., 13-15 May 2004, Badplaas. 55-58. 
COCHRANE KL (1987) The biomass and yield of the dominant fish species in Hartebeespoort Dam, South Africa. Hydrobiologia 146 89-96.

COETZEE PW (1977) The history and distribution of freshwater fish in Albany: largemouth bass. Albany Freshwater Angling Assoc. Newsletter 32 3-4.

COKE M and POTT R (1971) The Pongola Floodplain Pans. Limnol. Soc. Southern Afr. Newsletter 16 20-26.

COOKE SJ and COWX IG (2004) The role of recreational fishing in global fish crises. Bioscience 54 (9) 857-859.

COOKE SJ and PHILIPP DP (2009) Centrarchid Fishes: Diversity, Biology, and Conservation. Wiley-Blackwell. Chichester. 539 pp

COWX IG and GERDEAUX D (2004) The effects of fisheries management practises on freshwater ecosystems. Fish. Manage. Ecol. 11 $145-151$.

CRASS RS (1964) Freshwater fishes in Natal. Piscator 72 14-18.

DAVIES MTT (1986) Trout - whose responsibility? In: Skelton PH and Davies MTT (eds.) Trout in South Africa. Proceedings of a colloquium held in the JLB Smith Institute of Ichthyology, 9 April 1986. ICHTHOS Newsletter. 14-18.

DAY LA (1932b) The introduction of trout in Natal. Salmon and Trout Magazine 69 345-352.

DE MOOR IJ and BRUTON MN (1988) Atlas of Alien and Translocated Indigenous Aquatic Animals in Southern Africa. South African National Scientific Programmes Report No.144. CSIR, Pretoria. 310 pp.

DE SATGE R (1978) Perspectives on rural communities: some limitations. Collected Papers from the Symposium on Fisheries and Rural Development, 20-21 November 1978, Grahamstown, South Africa. 155-163.

DE VILLIERS P (1998) The management of fish populations in the Free State, South Africa: the philosophy. Proc. African Fishes and Fisheries: Diversity and Utilisation Conf., 13-18 September 1998, Grahamstown, South Africa.106.

DE VILLIERS P (2003) Freshwater fisheries conservation and management in South Africa with specific reference to the Free State province. In: Proc. $3^{\text {rd }}$ International Conference of the Pan-African Fish and Fisheries Association, 10-14 November 2003, Cotonou, Benin. 230-231.

DEDEREN JJ, FOUCHE PSO, GAIGHER IG, GAIGHER MJ, JOHN RP, LIGAVHA M, MASHAU E, MENNE PF, NETHONONDA LO, SZUBARGA A, TODD C, VAN DER WAAL BCW, VAN REE T, VENTER C, WOOD C and WEISSER P (2001) A sociobiological study of the aquatic resources and their utilisation in an underdeveloped rural region, the Mutshindudi River catchment. WRC Report No. 714/2/01. Water Research Commission, Pretoria. $150 \mathrm{pp}$.

DONNELLY BG (1965) The first record of rainbow trout breeding in the Port Elizabeth area. Piscator 64 91-92.

DU PLESSIS SS (1961) Trout Pioneer F C Braun (1875-1959) Fauna and Flora 12 17-23.

DU PLESSIS SS and LE ROUX PJ (1965) Sport fisheries in river development with reference to the Orange River Scheme. S. Afr. J. Sci. 61 (3) 137-146.

DU PREEZ M and LEE DE (2010) The contribution of trout fly fishing to the economy of Rhodes, North Eastern Cape, South Africa. Dev. S. Afr. 27 (2) 241-253.

DUNCAN-BROWN R (1980) Xonxa Fisheries Project: An attempt to stimulate angling in a rural community in Transkei. In: Transkei and Ciskei Research Society, Proc. $6^{\text {th }}$ Biennial Meeting, Umtata, 7-9 March, 1980. 160-161.

DWAF (DEPARTMENT OF WATER AFFAIRS AND FORESTRY, SOUTH AFRICA) (1997). Unpublished MS Excel Database of Water Resources. Department of Water Affairs and Forestry, Pretoria.

ECA (1989) Republic of South Africa, Environmental Conservation Act No. 73 of 1989.

ECCLES DH, HART RC, JACKSON PBN and TÓMASSON T (1983) Possible development options for fisheries: Distribution, structure and relative abundance of fish populations. In: Allanson BR and Jackson PBN (eds.) Limnology and Fisheries Potential of Lake le
Roux. South African National Scientific Programmes Report No. 77. CSIR, Pretoria. 161-171

ELLENDER BR (2008) The impact of angling on smallmouth and largemouth yellowfish, Labeobarbus aeneus and Labeobarbus kimberleyensis, in Lake Gariep, South Africa. M.Sc. Thesis, Rhodes University, South Africa. 111 pp.

ELLENDER BR, WEYL OLF and WINKER H (2009) Who uses the fishery resources in South Africa's largest impoundment? Characterising subsistence and recreational sectors on Lake Gariep. Water SA 35 677-684

ELLENDER BR, WEYL OLF, WINKER H and BOOTH AJ (2010a) Quantifying the annual fish harvest from South Africa's largest freshwater reservoir. Water $S A 36$ (1) 45-52.

ELLENDER BR, WEYL OLF, WINKER H, STELZHAMMER H and TRAAS GRL (2010b) Estimating angling effort and participation in a multi-user, inland fishery in South Africa. Fish. Manage. Ecol. 17 19-27.

ELLENDER BR, WEYL OLF and SWARTZ E (2011) Invasion of a headwater stream by non-native fishes in the Swartkops River system, South Africa. Afr. Zool. 46 39-46.

ENVIRO-FISH AFRICA (2009) Environmental impact assessment of the proposed eradication of Invasive Alien Fishes from selected rivers in the Cape Floristic Region. Executive summary. Final Environmental Impact Assessment Report.Prepared by EnviroFish Africa for Cape Nature. 14 pp. URL: www.fosaf.co.za/documents/Final\%20EIA\%20Report\%20Apr\%2009.pdf (Accessed 12 December 2011).

FAO (2003) Review of the state of the world fishery resources: inland fisheries. In: FAO Fisheries Circular. No. 942, Rev.1. FAO Inland Water Resources and Aquaculture Service, Fishery Resources Division, Rome. 60 pp.

FICK M (2009) Eastern Cape Fly-Fishers (ECFF) and Trout Action Group (TAG) Position Paper on Trout Zoning. URL: http://www. ecff.co.za/files/downloads/ECFF\%20TAG\%20Position $\% 20$ Paper\%20on\%20Zoning\%20Jan\%202009.pdf (Accessed 12 December 2011).

GABIE V (1965) Problems associated with the distribution of freshwater fishes in southern Africa. S. Afr. J. Sci. 61 (11) 383-391.

GAIGHER CM (1973) The Clanwilliam River: it is not yet too late? Piscator 88 75-78.

GEHEB K and BINNS T (1997) "Fishing farmers" or "farming fishermen"? The quest for household income and nutritional security on the Kenyan shores of Lake Victoria. Afr. Aff. 96 73-93

GRANEK EF, MADIN EMP, BROWN MA, FIGUIERA W, CAMERON DS, HOGAN Z, KRISTIANSON G, DE VILLIERS P, WILLIAMS JE, POST J, ZAHN S and ARLINGHAUS R (2008) Engaging recreational fishers in management and conservation: Global case studies. Cons. Biol. 22 1125-1134.

HAMMAN KCD (1980) Post-impoundment trends in the fish populations of the Hendrik Verwoerd Dam. J. Limnol. Soc. S. Afr.6 101-108.

HAMMAN KCD (1981) Aspekte van die bevolkingsdinamika van die Hendrik Verwoerddam met verwysing na die ontwikkeling van ' $n$ visserybestuurplan. Ph.D. Thesis, Rand Afrikaans University, South Africa. 208 pp.

HAMMAN KCD (1986) Alien fish species and conservation with special reference to the Cape Province. In: Skelton PH and Davies MTT (eds.) Trout in South Africa. Proceedings of a colloquium held in the JLB Smith Institute of Ichthyology, 9 April 1986. ICHTHOS Newsletter. 9-11.

HARRISON AC (1936) Black bass in the Cape Province: second report on the progress of American largemouth black bass. Department of Commerce and Industries, Fisheries and Marine Biological Survey Division, Union of South Africa. Investigational Report No. 7. 1-119.

HARRISON AC (1940a) The acclimation of freshwater game fish in the Cape province and its relation to forest areas. J. S. Afr. For. Assoc. 4 5-14

HARRISON AC (1948b) Report on the rivers of Maclear and East Griqualand, April and May 1948. Report No. 5, Inland Fisheries Department, Cape Provincial Administration. 15-19. 
HARRISON AC (1949) Freshwater Fishing in the Cape South Western Districts, South Africa. Cape Piscatorial Society, Cape Town. $20 \mathrm{pp}$.

HARRISON AC (1951) Introduction of exotic fishes to the Cape Province. Paper presented to the first interprovincial inland fisheries conference at Jonkershoek, Stellenbosch, December 1949. Piscator 6 52-61.

HARRISON AC (1952d) Introduction of exotic fishes to the Cape Province. Section III: black bass and bluegills. Piscator 22 57-64.

HARRISON AC (1952e) Introduction of exotic fishes to the Cape Province. Section III: black bass and bluegills (continued). Piscator 23 92-95.

HARRISON AC (1953a) Introduction of exotic fishes to the Cape Province. Section III: black bass and bluegills (continued). Piscator 25 12-15.

HARRISON AC (1953b) The acclimatization of smallmouth bass. Piscator 27 89-96.

HARRISON AC (1953c) Trout pioneering in the Eastern Province. No 8: Atlantic salmon and rainbow trout. Piscator 25 12-15.

HARRISON AC (1954b) Spotted bass in the Buffalo River. Piscator 30 39-40.

HARRISON AC (1954c) Trout pioneering in the Eastern Province. No 9: Drought, sea trout and farewell to Stenning. Piscator 30 47-53.

HARRISON AC (1957) A history of the freshwater fish associations of Cape Town. Piscator 41 214-226

HARRISON AC (1959) Editorial: the menace of carp. Piscator 46 44-53.

HARRISON AC (1962/63a) Notes on the introduction of smallmouth bass to the Berg River. Piscator 56 81-83.

HARRISON AC (1964/1965a) Spotted bass. Piscator 62 127-128.

HARRISON AC (1965/1966a) Slow-growing smallmouth bass in Steenbras reservoir. Piscator 65 117-119.

HARRISON AC (1966b) Early references to carp in the Cape colony. Piscator 6623.

HARRISON AC (1967/1968) Thirty years of smallmouth bass. Piscator 71 125-139.

HARRISON AC (1972/1973) Early records of trout stocking in the vleis of the Cape Flats. Piscator $\mathbf{8 6} 114$.

HARRISON AC (1975) The early transactions of the Cape Piscatorial Society. Part I. Piscator 94 69-75.

HART RC, ALLANSON BR and SELKIRK WT (1983) The biological basis of fish production. In: Allanson BR and Jackson PBN (eds.) Limnology and Fisheries Potential of Lake le Roux. South African National Scientific Programmes Report No. 77. CSIR, Pretoria. 26-64.

HECHT T and BRITZ PJ (1990) Aquaculture in South Africa: History, Status and Prospects. The Aquaculture Association of South Africa, Pretoria. 58 pp.

HEEG J and BREEN CM (1982) Man and the Pongola Floodplain. South African National Scientific Programmes Report No. 56. Cooperative Scientific Programmes, Pretoria. 117 pp.

HEY SA (1926a) Fisheries survey 1926-1927. Inland waters. Report No. 3. Department of Mines and Industries, Union of South Africa.

HEY SA (1926b) Preliminary report on the inland waters of South Africa with regard to the suitability for the introduction of edible fish. Inland waters. Report No. 1. Department of Mines and Industries, Union of South Africa.

HEY D (1941) The establishment and maintenance of freshwater fish in South Africa. J. S. Afr. For. Assoc. 6 3-25.

HEY D (1977) The history and status of nature conservation in South Africa. In: Brown AC (ed.) A History of Scientific Endeavour in South Africa. The Rustica Press (Pty.) Ltd, Cape Town. 132-163.

IMPSON ND, BILLS IR and WOLHUTER L (eds.) (2007) Technical report on the state of yellowfishes in South Africa. WRC Report No. KV 212/08. Water Research Commission, Pretoria. 198 pp.

JACKSON PBN (1973) Internal report on the potential of South African inland waters for commercial fisheries. Unpublished report to the Water Research Commission, Pretoria. 27 pp.

JACKSON PBN (1974) Freshwater fish for farm profit: Water, dams and management under the spotlight. Farmer's Weekly (October 1974). 42-47.
JACKSON PBN (1976) Water Resources and Freshwater Fisheries in southern Africa. In: Baker G (ed.) Resources of Southern Africa: Today and Tomorrow. The Associated Scientific and Technical Societies of South Africa, Johannesburg. 196-207.

JACKSON PBN (1980) Fresh and brackish water fish production as an employment source in the Transkei. In: Transkei and Ciskei Research Society, Proc. $6^{\text {th }}$ Biennial Meeting, Umtata, 7-9 March, 1980. 155-159.

JACKSON PBN (1981) Fish Harvesting. University of the Orange Free State: Publication Series C: No.3. 52-54.

JACKSON PBN (1981) Orange River dams fish population project. Rhodes University Institute for Freshwater Studies, Progress Report (August). Rhodes University, Grahamstown. 1-11.

JACKSON PBN, CAMBRAY JA, ECCLES DH, HAMMAN KCD, TÓMASSON T and WHITE PN (1983) Distribution, structure and relative abundance of fish populations. In: Allanson BR and Jackson PBN (eds.) Limnology and Fisheries Potential of Lake le Roux. South African National Scientific Programmes Report No. 77. CSIR, Pretoria, $182 \mathrm{pp}$

JACKSON PBN (1989) The value of introduced aquatic organisms to the sportfishing industry. Foundation for Research Development: Ecosystem Programmes Occasional Report Series No. 44. FRD, Pretoria, South Africa. 36-45.

JAGANYI J, SALAGAE M and MATIWANE N (2008) Integrating floodplain livelihoods into a diverse rural economy by enhancing co-operative management: A case study of the Pongolo floodplain system, South Africa. WRC Report No. 1299/1/08. Water Research Commission, Pretoria. 423 pp.

JOUBERT P (1984) Daar's baars in die Vaal. Stywe Lyne (January 1984) 5-7.

JUBB RA (1962) Prospects for an eel fishery. Piscator 56 84-85.

JUBB RA (1972a) Disappearing river fishes. Afr. Wildlife 26 (2) 48-52.

JUBB RA (1973) The JG Strydom Dam: Pongolo River: northern Zululand. The importance of the floodplain pans below it. Piscator 86 104-109.

JUBB RA (1973a) Notes on exotic fishes introduced into South African inland waters. Piscator 87 9-12.

JUBB RA (1973b) Notes on exotic fishes introduced into South African inland waters: cyprinids. Piscator 88 62-64.

KAPETSKY JM (2003) Overview of inland capture fisheries. In: FAO Inland Water Resources and Aquaculture Service, Fishery Resources Division. Review of the state of world fishery resources: inland fisheries. FAO Fisheries Circular. No. 942. Rev. 1. FAO, Rome. 60 pp.

KAPETSKY JM and PETR T (1984) Status of African reservoir fisheries. CIFA Technical Paper No. 10. 1-325.

KOCH BS and SCHOONBER HJ (1980) A fish mark-recapture study in Boskop Dam, Western Transvaal. Water SA 6 149-155.

KOEKEMOER JH and STEYN GJ (2005) Fish community study of Hartebeespoort Dam. Final Report. Department of Agriculture, Conservation, Environment and Tourism, North West Province, South Africa. $101 \mathrm{pp}$.

LA' HAUSSE' DE' LALOUVIERE P (1987) A brief review of the state of knowledge of the fishes and fishery of the Pongolo floodplain, northern Zululand. Institute of Natural Resources, Pietermaritzburg. 13 pp.

LE ROUX PJ (1961) Growth of Tilapia mossambica Peters in some Transvaal impoundments. Hydrobiologia 18 165-175.

LE ROUX PJ (1965) The magnitude of freshwater angling in the Transvaal. Fauna \& Flora 16 38-39.

LEIBOLD M and VAN ZYL CJ (2008) The economic impact of sport and recreational angling in the Republic of South Africa, 2007: Extensive Report. In: Development Strategies International (Pty.) Ltd (eds.). Report of project to scientifically determine the overall economic impact and strategic value of sport \& recreational angling in the Republic of South Africa. Development Strategies International (Pty.) Ltd. 49 pp.

LOWE SR, WOODFORD DJ, IMPSON ND and DAY JA (2008) The impact of invasive fish and invasive riparian plants on the invertebrate fauna of the Rondegat River, Cape Floristic Region, South Africa. Afr. J. Aquat. Sci. 33 51-62. 
MABITSELA CK (1981) An ecological investigation of the economically viable fish species in certain dams in Lebowa, South Africa. M.Sc. Thesis, University of the North, South Africa.

MACDONALD IAW, KRUGER FJ and FERRAR AA (eds.) (1986) The Ecology and Management of Biological Invasions in Southern Africa. Oxford University Press, Cape Town. 324 pp.

MANNING DW (1908) Trout Fishing in the Cape Colony, Argus Printing and Publishing Ltd., Cape Town. 97 pp.

MARSHALL B and MAES M (1994) Small water bodies and their fisheries in southern Africa. CIFA Technical Paper No. 29. FAO, Rome. 68 pp.

McCAFFERTY JR, WEYL OLF and SWARTZ E (2010) Why should the Department of Agriculture, Forestry and Fisheries consider recreational angling in its long-term plans for inland fisheries? In: Proc. 14 ${ }^{\text {th }}$ Yellowfish Working Group Conf., 16-17 April, 2010. 147-151.

McVEIGH SJ (1978) A preliminary survey of the impoundments of the Western Cape with regard to angling and the development of angling facilities. Report to the Cape Department of Nature and Environmental Conservation, South Africa. 63 pp.

McVEIGH SJ (1979a) Bass in farm dams. The Cape Angler 5 6-14.

MERRON GS and TÓMASSON T (1984) Age and growth of Labeo umbratus (Pisces: Cyprinidae) in Lake le Roux on the Orange River, South Africa. J. Limnol. Soc. S. Afr. 10 5-10.

MERRON GS, BRUTON MN and LA'HAUSSE' DE'LALOUVIERE $P$ (1993) Implications of water release from the Pongolapoort Dam for the fish and fishery of the Phongola Floodplain, Zululand. S. Afr. J. Aquat. Sci.19 (1/2) 34-49.

MERRON GS and WELDRICJ SK (1995) Fisheries management of the Phongola floodplain. Investigational Report No. 51. J.L.B. Smith Institute of Ichthyology, Grahamstown. 129 pp.

MYERS GS (1965) Gambusia, the fish destroyer. Tropical Fish Hobbyist (January) 31-32; 53-54.

NESS J (1991) Notes on the introduction of trout to the Western Cape and the origins of the Cape Piscatorial Society. Piscator 12325.

NEILAND AE, CHIMATIRO S, KHALIFA U, LADU BMB and NYEKO D (2005) Inland fisheries in Africa: Key issues and future investment opportunities for sustainable development. Technical Review Paper - Inland Fisheries. URL: www.fishforall.org/ffa summit/C Eg/Inland\%20Fisheries\%20Review\%20Paper.doc (Accessed 7 October 2010). NEPAD. 76 pp.

NEMA (1998) Republic of South Africa, National Environmental Management Act No. 107 of 1998.

NEM:BA (2004) Republic of South Africa, National Environmental Management: Biodiversity Act No. 10 of 2004.

NOBLE RG and HEMENS J (1978) Inland Water Ecosystems in South Africa - A Review of Research Needs. South African National Scientific Programmes Report No. 34. CSIR, Pretoria. 150 pp.

NWA (1998) Republic of South Africa, National Water Act No. 36 of 1998.

OLDS AA, SMITH MKS, WEYL OLF and RUSSELL IA (2011) Alien invasive freshwater fishes in the Wilderness Lakes system, a wetland of international importance, Western Cape, South Africa. Afr. Zool. 46 179-184.

PIENAAR U (1978a) The Freshwater Fishes of the Kruger National Park. National Parks Board of South Africa, Pretoria. 91 pp.

PIKE T (1980a) An historical review of freshwater fish hatcheries in Natal. Piscator 106 49-53.

CAPE PISCATORIAL SOCIETY (2010) History. URL: www.Piscator. co.za (Accessed 5 September 2010).

POLLARD S and COUSINS T (2008) Community-based governance of freshwater resources in southern Africa. WRC Report No. TT 328/08. Water Research Commission, Pretoria. 106 pp.

POTT R (1973) Anglers - your help is needed. Fauna \& Flora 24 1-3

POTTS WM (2003) Towards the development of species-specific fish production models for small reservoirs in southern Africa. Ph.D. Thesis, Rhodes University, South Africa. 148 pp.

POTTS WM, WEYL OLF and ANDREW TG (2004) Final report on an initial assessment of the fisheries potential of Gariep Dam Prepared by: Enviro-Fish Africa (Pty) Ltd for: Department of Economic Affairs, Environment and Tourism, Northern Region, Province of the Eastern Cape. 38 pp.
POTTS WM, BOOTH AJ, HECHT T and ANDREW TG (2006) The life history and fishery potential of Labeo umbratus (Teleostei: Cyprinidae) in five small South African reservoirs. Afr. J. Aquat. Sci. 31 (2) 285-295.

RICHARDSON TJ, BOOTH AJ and WEYL OLF (2009) Rapid biological assessment of the fishery potential of Xonxa Dam, near Queenstown, South Africa. Afr. J. Aquat. Sci 34 87-96.

ROODE MC (1978) Harvesting of freshwater fish from natural resources: a marketing experiment conducted in the Transkei. Fish Farmer Transvaal Newsletter 20 2-12.

ROUHANI Q (2001) A report on an assessment of the potential for small-scale fisheries development on Disaneng and Setumo dams in the North-West Province. Rural Fisheries Programme, Department of Ichthyology and Fisheries Science, Rhodes University. 17 pp.

ROUHANI Q (2003) Report for the assessment of the potential for community based small-scale fisheries in Ntenetyana Dam (Alfred Nzo District Municipality). Rural Fisheries Programme, Department of Ichthyology and Fisheries Science, Rhodes University. $12 \mathrm{pp}$.

ROUHANI Q (2004) A report on the survey of selected large dams in the North West Province: with a view to develop fisheries. Report for the Department Agriculture Conservation and Environment, North West Province, South Africa. 328 pp.

ROUHANI Q and ANDREW TG (1998) Freshwater fisheries for rural development in the Eastern Cape Province of South Africa. Proc. African Fishes and Fisheries: Diversity and Utilisation Conf., 13-18 September 1998, Grahamstown, South Africa. 168.

ROUHANI Q and DAVIES MTT (2003) A report on the survey to determine the potential for recreational and subsistence fisheries in the Alfred Nzo District Municipality. Rural Fisheries Programme, Department of Ichthyology and Fisheries Science, Rhodes University. 20 pp.

ROUHANI Q and BRITZ PJ (2004) Contribution of aquaculture to rural livelihoods in South Africa: a baseline study. WRC Report No. TT 235/04. Water Research Commission, Pretoria. 105 pp.

ROUHANI Q, HINRICHSEN E and DAVIES MTT (2010) Cata Recreational Fisheries Report: On the feasibility and business plan to develop a recreational fishery in and around Cata Dam. Rural Fisheries Programme, Department of Ichthyology and Fisheries Science, Rhodes University. 48 pp.

ROUX DJ, NEL JL, MACKAY HM and ASHTON PJ (2006) CrossSector Policy Objectives for Conserving South Africa's Inland Water Biodiversity. WRC Report No. TT 276/06. Water Research Commission, Pretoria. 100 pp.

RYDER RA (1965) A method for estimating potential fish distribution of North-temperate lakes. Trans. Am. Fish. Soc. 94 214-218.

SAAYMAN JE, JOOSTE A, OLIVIER PAS, MOKGALONG N and POLLING L (1983) The cropping potential of Nzhelele Dam, Republic of Venda. Research report prepared for the Venda Development Corporation. 12 pp.

SARCH MT and ALLISON EH (2000) Fluctuating fisheries in Africa's inland waters: Well adapted livelihoods, maladapted management. Proc. $10^{\text {th }}$ International Conf. of the Institute of Fisheries Economics and Trade, 9-14 July 2000, Corvallis, Oregon, USA. $11 \mathrm{pp}$.

SCHLESINGER DA and REGIER HA (1982) Climatic and morphoedaphic indices of fish yields from natural lakes. Trans. Am. Fish. Soc. 111 (2) 141-150.

SCHOONBEE HJ, HECHT T, SAAYMAN JE and POLLING L (1995) Fish population assessment in a temperate Lowveld impoundment of the Transvaal, South Africa. Water SA 21 (2) 147-152.

SCHRAMM M (1993) A comparison of Cyprinid fish populations in three large Transkei reservoirs with respect to abundance and reproduction. S. Afr. J. Aquat. Sci. 19 74-88.

SCOTT HA (1982) The Olifants River system: unique habitat for rare Cape fishes. Cape Conservation Series 2.Cape Department of Nature and Environmental Conservation.

SETI S (2002) Small-scale fisheries as a vehicle for rural development: a case study of two villages in the former Ciskei, Eastern Cape Province, South Africa. M.Sc. Thesis, Rhodes University, South Africa. 198 pp. 
SKELTON PH (1983) Perspectives on the conservation of threatened fishes in southern Africa. The Naturalist 27 (1) 3-12.

SKELTON PH (2001) A Complete Guide to the Freshwater Fishes of Southern Africa (2nd edn.). Struik Publishers, Cape Town. 395 pp.

SKELTON PH and DAVIES MTT (eds.) (1986) Trout in South Africa Proceedings of a colloquium held in the JLB Smith Institute of Ichthyology, 9 April 1986. ICHTHOS Newsletter.

SKELTON PH and WEYL OLF (2011) Fishes. In: Picker $\mathrm{M}$ and Griffiths C (eds.) Alien \& Invasive Animals: A South African perspective. Struik Nature, Cape Town. 47-70.

SMITH W (1984) Count down for SA bass team. Tight Lines (October 1984) 14-18.

SMITH CL (1986) The life cycle of fisheries. Fisheries 11 (4) 20-22.

STADTLANDER T, WEYL OLF and BOOTH AJ (2011) New distribution record for the Asian tapeworm Bothriocephalus acheilognathi Yamaguti, 1934 in the Eastern Cape province, South Africa Afr. J. Aquat. Sci. 36 (3) 339-343.

SWARTZ E (2009) Personal Communication, Dr E Swartz, Senior Scientist, South African Institute for Aquatic Biodiversity, P Bag 1015, Grahamstown 6140, South Africa

TAYLOR L and VAN DER WALT IS (1985) Aspects concerning the fish and fisheries development in Lebowa. Fish Farmer 37 9-11.

TINLEY KL (1964) Fishing methods of the Thonga tribe in northeastern Zululand and southern Mocambique. Lammergeyer 3 9-39.

TÓMASSON T (1983) The biology and management consideration of abundant large cyprinids in Lake le Roux, Orange River, South Africa. Ph.D. Thesis, Rhodes University, South Africa. 218 pp.

TÓMASSON T, CAMBRAY JA, ECCLES DH, JACKSON PBN and WHITE PN (1983) Fisheries of Lake le Roux. In: Allanson BR and Jackson PBN (eds.). Limnology and Fisheries Potential of Lake le Roux. South African National Scientific Programmes Report No. 77. CSIR, Pretoria. 153-160.

TÓMASSON T, BRUTON MN and HAMMAN KC (1985) The demography and management of large Cyprinids in a reservoir on the Orange River, South Africa. Fish. Res. 3 279-308.

VAN DEN BERG RA, GAIGHER IG and LENYAI SK (1975) The use of small farm dams in the Transkei and Ciskei for the production of table-fish using Aischgrund carp. Limnol. Soc. S. Afr. 1 11-15.

VAN DER KNAAP M (1994) Status of fish stocks and fisheries of thirteen medium-sized African reservoirs. CIFA Technical Paper No. 26.FAO, Rome. 107 pp.

VAN DER WAAL BCW (1978a) Status of fisheries of black states of South Africa. Collected Papers from the Symposium on Fisheries and Rural Development, 20-21 November 1978, Grahamstown, South Africa. 171-179.

VAN DER WAAL BCW (1978b) Suggestions towards a fisheries development policy for the black states of South Africa. Collected Papers from the Symposium on Fisheries and Rural Development, 20-21 November 1978, Grahamstown, South Africa. 165-170.

VAN DER WAAL BCW (2000) Fish as a resource in a rural river catchment in the Northern Province, South Africa. Afr. J. Aquat. Sci. 25 56-70.
VAN RENSBURG KJ (1963) A review of the status of the Olifants River yellow-fish, Barbus capensis. Department of Nature Conservation, Cape Provincial Administration. Report No. 20. Cape Provincial Administration, South Africa. 73-75.

VAN RENSBURG BJ, WEYL OLF, DAVIES SJ, VAN WILGEN LJ, PEACOCK DS, SPEAR D and CHIMIMBA CT (2011) Invasive vertebrates of South Africa. In: Pimentel D (ed.) Biological Invasions: Economic and Environmental Costs of Alien Plant, Animal, and Microbe Species ( $2^{\text {nd }}$ edn.). CRC Press, Boca Raton, Florida. 326-378.

VAN DEN BOSSCHE JP and BERNACKSEK GM (1990) Source book for the inland fishery resources of Africa. CIFA Technical Paper No. 18.1. FAO, Rome. 411 pp.

WALMSLEY RD and PIKE T (1989) Current legislation and conservation policy on invasive aquatic animals in South Africa and adjacent states. Foundation for Research Development Ecosystems Programmes Occasional Report Series. FRD, Pretoria, South Africa. 57-67.

WASSERMANN RG, STRYDOM N and WEYL OLF (2011) Diet of largemouth bass, Micropterus salmoides (Centrarchidae), an invasive alien in the lower reaches of an Eastern Cape river, South Africa. Afr. Zool. 46 (2) 378-386.

WEIR JC (1972) Diversity and abundance of aquatic insects reduced by introduction of the catfish Clarias gariepinus to pools in Central Africa. Biol. Cons. 4 169-175.

WEYL OLF, POTTS WM, ROUHANI Q and BRITZ PJ (2007) Theneedfor an inland fisheries polic yin South Africa: A case study on the Northwest Province.Water SA 33 497-504.

WEYL OLF, BOOTH AJ, WINKER H, TRAAS GRL, McCAFFERTY JR, PEEL RA and WARTENBERG R (2010a) Assessment of the fishery potential for alien species on Darlington Dam. Report No. 5. SAN-Parks: Sundays River Freshwater Fish Research Project, Project ID: PO64438. 1-59.

WEYL OLF, RIBBINK AJ and TWEDDLE D (2010b) Lake Malawi: fishes, fisheries, biodiversity, health and habitat'. Aquat. Ecosyst. Health Manage. 13 (3) 241-254. DOI: 10.1080/14634988. 2010.504695

WEYL PSR, DEMOOR FC, HILL MP and WEYL OLF (2010c) The effect of largemouth bass Micropterus salmoides on aquatic macroinvertebrate communities in the Wit River, Eastern Cape, South Africa. Afr. J. Aquat. Sci. 35 (4) 273-282.

WHITEHEAD DRC (1978) Practical aspects and economics of exploiting natural fisheries in large impoundments. Collected Papers from the Symposium on Fisheries and Rural Development, 20-21 November 1978, Grahamstown, South Africa. 155-163.

WINKER H (2007) What can be learnt from angling competitions in large South African dams. Rhodes University Department of Ichthyology and Fisheries Science, Research Report Series 19. Rhodes University, Grahamstown.

WRC (2011) Water Research Commission Abridged Knowledge Review 2010/11. Water Research Commission, Pretoria. 
http://dx.doi.org/10.4314/wsa.v38i2.18 Available on website http://www.wrc.org.za

ISSN 0378-4738 (Print) = Water SA Vol. 38 No. 2 April 2012 ISSN 1816-7950 (On-line) = Water SA Vol. 38 No. 2 April 2012 